Portland State University

PDXScholar

$9-1-1970$

\title{
The European powers in Africa : can the obstacles to national unity be attributed to them? Nigeria, a test case
}

Bassey John Ituen

Portland State University

Follow this and additional works at: https://pdxscholar.library.pdx.edu/open_access_etds Let us know how access to this document benefits you.

\section{Recommended Citation}

Ituen, Bassey John, "The European powers in Africa : can the obstacles to national unity be attributed to them? Nigeria, a test case" (1970). Dissertations and Theses. Paper 794.

https://doi.org/10.15760/etd.794

This Thesis is brought to you for free and open access. It has been accepted for inclusion in Dissertations and Theses by an authorized administrator of PDXScholar. Please contact us if we can make this document more accessible: pdxscholar@pdx.edu. 
AN ASSPRACT OF THE THESIS OF Eassey John Ituen for the

Mastex of Nrts in History presented September 30, 1970.

Titlel The European Powers in Afrlca: Can the obstacles to Nationel Unity be attributed to them? Nigeria, a Test Case.

APPROVED SY MEMBERS OF THE THESIS CONMITTEE!

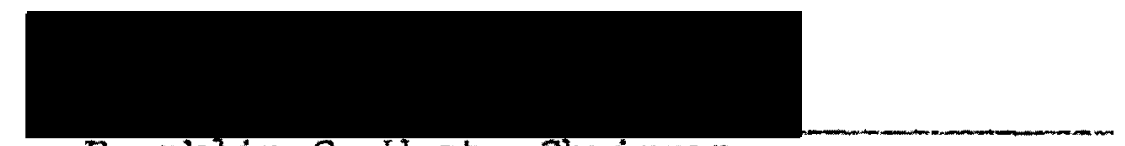
Franklin C, West, Chairman

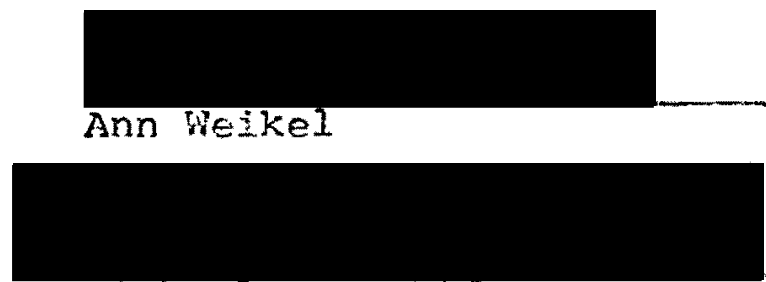

Michael F, Reardon

During the latter part of the nineteenth century, Buropean powers acquired large territorial areas in nfrica. These territories ignored the boundaries of oid ifrican tribal kingdoms and the Afrjcan modes of life, because the new countries were to serve as 'common market' areas supplying burope with the wealth of the tropics. Nigeria is an example of the new suporstructure which in operatior falls to become a romogeneous entity alyer the assumpiof of political poros by the ifricans. There are problems of existing tribal kingdoms, of geographic 
distribution of ethnic groups and of traditional values. The British colonization of Nigeria also brought about regional distribution of Western ideas and differing attitudes among Nigerians. The problems, politically, sociologically and economically, are imbedded in present day Nigerian society. The British attempt to build Nigeria as an economic area has produced certain centripetal forces which are revealed in the growth of urbanization with resulting detribalization, means of communication with the concomitant social mobility, and the educational facilities with its new breed of Nigerians. The building of national consciousness and political stability are faced with centrifugal forces which are really probleins of change introduced by the Europeans and accepted by the Africans. At the same time, the forces of change are challenged by traditional factors which still weigh on the Nigerian mind. 
TO THE OFFICE OF GRADUITE STUDIES:

The menhers of the committee approve the

thesis of Eassey Joln rtuen presented September 30, 1970
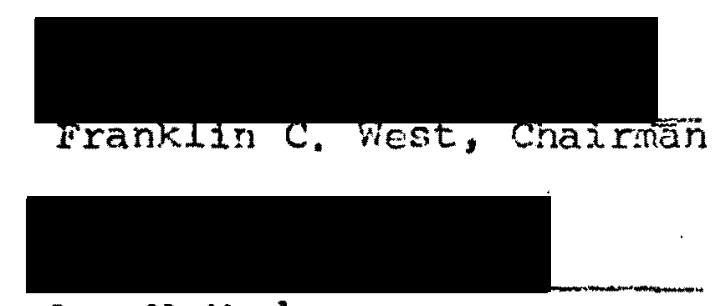

Ann Weikel

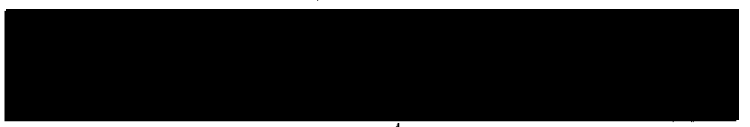

Michael F. Reárdon

APPROVED:

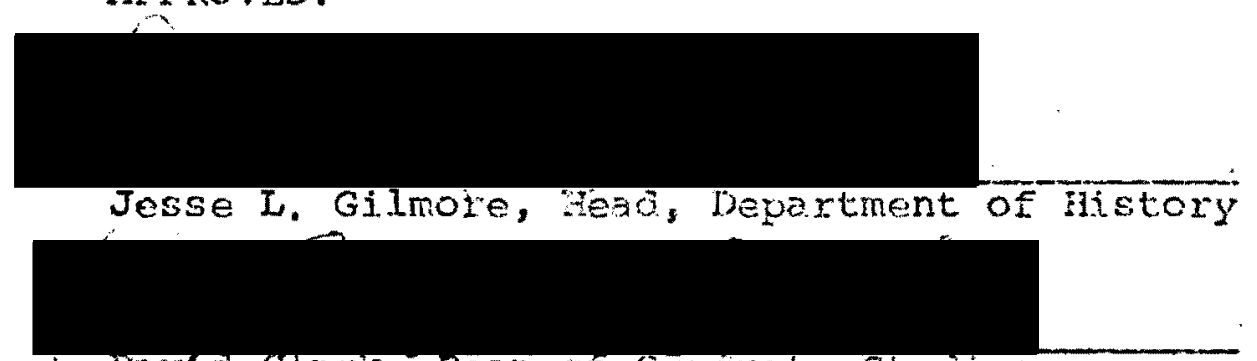

CDav1a cJark, Dean of Graduate Stuaies

October 5,1970 
THE EUROPEAN POWERS IN AFRICA:

CAN THE OBSTGCLES TO NATIONAL UNITY BE

ATTRIBUTED TO THEN NICERIA, A MEST CASE

by

BASSEY JOHN TTUER

A thesis submitted in partial ful-
fillment of the requirements for the
degree of

MASTER OF ARTS

in

HISTORY

Portland State University

1970 
TABLE OF CONTENTS

PAGE

CHAPTER

I INTRODUCTION ............. 1

II HISTORICAL BACKGROUND........ 4

III THE PROBLEMS OF UNITY....... 26

Centrifugal Forces....... 26

Existence of ancient kingdoms......... 26

Presence of many cultures.. $\quad 32$

Area variation in religion 33

Lack of Lingua Franca...... 42

Cross-regional settlement of people...... 44

Trans-territorial settlement of people..... 45

Existence of many ethnic groups........ 47

Tribal political parties... 52

Regional control of federal government..... 58

Geographic distribution of population..... 64

Differing land laws....... 65 
III THE PROBLEMS OF UNITY (cont.)

population census and political power............

Differences in acquistuion of Westerr ideas.... 73

Differing attitudes of Nigerians 75

Differing aspects of British administration.... 79

Centripetal Forces........... 80

Attempt to build an ecoromic area.......... 88

Construction of cormunication media.......... 89

Growth of new towns......... 90

Establishment of educational centers......... 91

IV CONCLUSION................ 94

BIBLIOGRAPHY.................... 98 


\section{CHAPTER I}

INTRODUCTION

The purpose of the study is to analyse the problems of national unity in one of the African countries and see whether such problems must be attributed to the European Powers which partitioned Africa. The study is not a vindication of colonial rule, but presents a critical viewpoint as far as those problems are concerned.

Nigeria will serve as the country under study. It is selected because it contains the largest concentration of black Africans who might be assumed to be homogeneous. Moreover, immediately after independence Nigeria was labelled by the Western nations as a bastion of democracy. Its mere size creates problems as far as national unity is concerned. In addition to this, the civil war in Nigeria and the reaction of the African heads of state and other world leaders afford a very suitable occasion to examine the problems of national unity.

Mention must also be made of another factor which induced me to pick Nigeria. As a Nigerian I have seen a little bit of the two worlds--the colonial era and the independence period of the country. As a resident of a coalesced community-three villages of about twenty thousand or more people who claim 
a common descent and mores, and live under one group head as their secular leader--I could observe some of the problems at the local level. And as an elected representative of this community in a county council which was formed by joining two county councils, or rather two clans--Ibesikpo and Asutan--I witnessea some of the problems of unity at the grass roots. Political though such experience may be, it provided strong evidence for the 'play it cool' attitude of the traditional members in matters of unity. It also afforded evidence against the former civilian regional government in non-government party areas, their allocation of amenities, and their role on minority issues.

Materials for this study are based on docunentary evidence which include journals, case studies of Nigeria in general, and iny personal experience as a Nigerian. Although red tape has forestalled the gathering of opinions from some Africans, especially the Nigerian leaders, a number of Nigerians and other African students have freely expressed their opinions about European powers and national unity in Africa. All the same, various Africans in public life have written books re-

1

Obafemi Awolowo, Path to Nigerian Freedom. London, Faber, 1947. 1943. Nnamdi Azikiwe, Political Blueprint of Nigeria. Lagos, T. Olawale Elias, Q.C., Government and Politics in Nigeria. New York, 1963. Kwame Nkrumah, Afxica Must Unite. F.A. Proeger, New York, 1963. Tom Mboya, Freedom and After. Iittle Browr and Co., Boston, 1963. 
lated to this subject, and their own opinions pertinent to this paper were consulted. But the opinions of these African writers do not affect my own conclusions since I am trying to present a critical point of view of the national problems. The attempt of writing either African history or presenting African problems with sympathy is much reduced.

In addition to the basic source materials there were other isolated parts gathered from some newspapers and magazines. An extensive bibliography has been added at the close of the thesis. African oral history, although it could not be documented, has helped in forming some opinions; and I would like to credit my late uncle, Chief Abakada (Bassey) Ituen, a traditional ruler, a spiritual leader and great oral historian of the Ibesikpo clan who was consulted by the British administrators during the era of clan and division formation. 
CHAPTER II

HISTORICAL BACKGROUND

Africa is labelled as the Dalk Continent. The phrase itself suggests that Africa was a backwater area of Western European penetration. Interestingly enough, the Romans had colonized a greater part of North Africa though not beyond the Sahara. The Arabs through Islam and the caravan trade had penetrated much of Africa. Not even the Sahara was a barrier for Morocco and Tripoli, the caravan trading centers on North Africa, were cornected with the trading centers of the Western Sudan such as Timbuktu and Kano in what are now Mali and Nigeria respectively. The Red Sea trade, on the other hand, brought Arabic-speaking peoples into East and Central Africa. If the ottoman Empire is regarded as a part of the Eastern European affairs, this empire had dependencies in Egypt, Tripoli, Tunis and Algiers. South Africa also experienced the East. African influence of the Arab traders; such influence was very minimal. The sea voyage of Vasco da Gama, a Portuguese, with his successful rounding of the cape of Good Hope in 1498 opened South Africa to European eyes; however, it was 1652 before a group of Dutch settlers planted a colony at Cape Town. In spite of such western European settlement, much of Africa was a trading domain for the Moslem Arab traders. But at the 
same time, some western European nations were coming in contact with some of the coastal city-states of certain areas of Africa. The Portuguese were the first western European nation to reach the Guinea coast of the Western Sudan, and to land their 1

first crews in Benin in 1472. Benin was not only a prosperous commercial center, but also a powerful kingdom in the forest land of the Guinea coast. The Portuguese through Alfonso d'Aveiro opened the first diplomatic relations with the ruler of Benin in 1485. Thus the portuguese contact expanded the trade of Benin. The Benin trade on the forest products such as peppers and ivory soon was opened to another western European nation. In 1553 a British sea captain, winham, made the first English voyage to Guinea and Benin. The English expedition into Benin did not only expand the Benin trade but it also upset the tone of the Portuguese trade; for the English traders became interested in the local slave trade, and thus gave it a new impetus. Between 1600 and 1800 western European nations became interested in geographical exploration of Africa. In 1796 Mungo Park and other Englishmen arrived at the Guinea Coast to trace the source and the course of the river Niger. In $1823 \mathrm{Clapperton}$ and his crew arrived at Kuka in Bornu, Kano in Hausaland, and Sckoto in the Fulani empire. Richard Lancier

1

Benin is now the capitol of the Midwest state in Nigeria. The state is mainly inhabited by the Edos, the Urobos, the western Ibos, and the western Ijaws. 
with his tean reachea Brass at the mouth of the witger in i830. David Livingstone led en expedition In $_{1853}$ along the zambai river; while Sir Richard Burton in 1850 explored lake Tanganyika on the east Coast of Africa. Between 1858 and 1862 Captain Speke explored the lacustrine region of Uganda. In 1877 E.M. Stanley, who was later employed in the services of King Leopuld II of Belgium, surveyed much of the Corgo basin; but the exploration of the Congo region soon attracted savorgnan de Brazza of France. By means of trade and geographical exploration Western European nations penetrated into Africa, and later laid claims to certäin African territories. Even though the Portuguese were the first European nation to arrive in the Benin Kingdom, the area of what is now terned Nigeria was largely influenced by the British. In 183.3, the slave trade was abolished and the British turned their attention to promoting legitimate trade along the Guinea coast. In 1849 the British established their first consulate at calabar. To suppress the slave trade, the British consulate found it necessary in 1861 to attach and colonize Lagos, then a major slave-dealing center. British influence was thus estaolished at Lagos colony and the adjacent areas. The establishment of the colony of Iragos was the first direct involvement by the British government, and the citizens of Lagos were regarded as British subjects. Calabar, the consulate headquarters, served as a stepping stone to the creation of the Oil Rivers Protect- 
orate or the Niger Coast Protectorate which was proclaimed on June 5, 1885. The Niger Coast Protectorate was only a trading area open to many European firms; but this area was directly influenced by the Consulate. The inhabitants of this oil Rivers Protectorate, quite unlike those of Lagos, were regarded as British protected persons.

The amalgamation of the various trading firms on the Niger by Sir Taubman Goldie, and the granting of a charter to the company so formed allowed the Royal Niger Company to rule from 1886 until December 1899 in territories with which the agents of the company had signed treaties. The company's territory expanded along an ever-moving frontier as its agents moved inland. In theory it extended as far as Katsina and Bornu in Northern Nigeria; and in the southwest it covered 3

New Calabar, Brass and parts of the present Midwest State; and to the southeast it extended to old Calabar, the consulate headquarters. Treaties were signed to claim areas of influence on the parts of the chiefs, but the territorial area of the chief was limited according to his ability. If he was a wealthy and powerful chief it may take in pockets and hamlets

2

The treaties as understood by the chiefs and the people of the area were not a political hand-over of their territories but they were to allow a peaceful penetration of the company's merchants.

3 This is Bonny area along the Bight of Biafra. 


\section{4}

of his in-laws. The company's texritorial area was a trade area, nay, a service area. To stabilize its spheres of influence the Royal Niger Company set up a military headquarters at Lokoja, a town at the confluence of the Niger and the Benue. The stationing of troops in Northern Nigeria helped in the pacification of the Fulani emirates. The company also established another headquarters at Asaba on the Niger delta to undertake both ruling anö trading responsibilities. Between 1897 and 1898 the Royal Niger Company broke its clauses of the charter by monopolizing the trade, and had to fight the angry Asaba traders who burnt their headquarters. The charter was therefore revoked very reluctantly by Her Majesty's Government, for many British taxpayers did not want to assune the increased financial burden of administering the colonies. Furthermore, many of them believed that the desire for colonies had been the cause of most of the wars during the earlier hundred and sixty years. It was in 1900 when the British Government took over the control of the colony of Lagos, the Niger Coast Protectorate and the Royal Niger Company's territory, and christened the new protectorate, Nigeria, a name which first appeared in The Times, the British government as such now became directly involved with the adminisitration of Nigeria. The new country was divided into three administrative

4 chief may marry more than one wife, and alj. the wives do not come from one village.

5 Federal Ministry of Information, Nigeria 1960: A Special Independence Issue of Nigeria Magazine, October 1960, (Federal Government Printer, Lagos, Nigeria, 1960) p.9. 
units: the Colony of Lagos, the protectorate of Southern Nigeria, and the Protectorate of Northern Nigeria. The new administrative divisions involved major adjustments in the former territories of the Oil Rivers Protectorate and the Royal Niger Company. It must be emphasized that the groundwork for the acquisition of territories had been laid by the British firms which by various means bought off other nonBritish firms. The British government was orly taking up trade areas of their firms; and although there was fighting in Northern Nigeria from 1900 to 1906, it was the result of the pacification program, and the establishment of the British government's influence.

By 1906 the Colony of Lagos which was separately administered was unified with the Protectorate of Southern Nigeria. Even though the Colony of Lagos was brought under the administration of the Southern Protectorate for a period of forty-five years (1861-1906), the separate identity of Lagos had been a reality, particularly in outlook and institutions. In 1914, the Colony and the Southern Protectorate, and the Protectorate of Northern Nigeria were amalgamated under one governor-general, but were not uniformly administered. The amalgamation caused many administrative problems, some no doubt can be attributable to how Great Britain and other European nations reacted to the assassination of Francis Ferdinand rather than to the uncongenial climate of Nigeria. There was a general lack of British staff to run the country; and the territory was very large. In addition there was the problem 
of getting enough money for the administration. Thus a unified Nigeria was born in the year when British finance and manpower were strained by the First World War. 6

Lord Lugard, who had served the Royal Niger Company as an agent, became the first British Governor-general in the amalgamated protectorates. Lord Iugard, therefore, resorted to a system of Indirect Rule which entrenched and stabilized autocratic and conservative emirs who supported British interest. It is true that Indirect Rule recognized the importance of indigenous adninistration and furthermore reduced the high cost of bureaucracy, but Lord Iugard was disdainful of the few educated Nigerians since he felt they had nothing in common with the masses. Most of the Nigerian elite were not members of the royal families to be appointed as chiefs and emirs; and as such they were denied an opportunity of laying the administrative foundation of a unified Nigeria. The Nigerian bourgeoisie saw indirect rule as presenting a division between the new breed and the traditional rulers. Indirect rule perpetuated the traditional political units of varying sizes in which clannish attitudes and loyalties had their roots. Aside

6

In 1894 Lugard rushed to Borgu and made a treaty with the chiefs to prevent the French from acquiring all of Kiama and Nikki territory into Dahomey.

\section{7}

T. Olawake Elias, Q.C., Government and Polities in Africa, (New York: Asia Publishing House, 1963), p. 24. See also Lord Arthur Lugard, The Dual Mandate in Tropical Pfrica, (London, 1922). 
from Northern Nigeria, Yorubaland and Bini area, there were no large scale political organizations, conseguently most Nigerians, especially those from the South, lacked administrative experience for running a large political unit. The weaknesses of Iord Lugard's system notwithstanding, indirect rule aimed at stability of the Nigerian society and securing law and order which would foster British economic interests. Apart from a few incidents--the Aba riot of 192.9 in which women opposed general taxes; the shooting of Enugu coal mine strikers demanding faix wages in 1949, and the Kano riot of 1953 in which the Northerners fought the Southerners--indirect rule ushered in the Pax Britannica. The system became a model for British colonial government in East Africa.

The disdainful attitude of Lord Lugard to the Nigerian inteliligentsia became the hallmark of colonial administration. From 1923 to 1945 the Nigerian Legislative Council excluded many educated Nigerians from the administrative and policymaking arms of the government. Only four Africans represented the Southern Protectorate while the North had no African representation. Three members represented the township of Lagos,

\section{8}

Indirect rule was first introduced into Northern Nigeria where the emirs ruled large emirates before the advent of the British. In the South the areas ruled by the chiefs were small and at times not larger than the village.

\section{9}

Report on the Administration of Southern and Northern Nigeria, and Administration, 1912-1919. Cmd. 468 (Longon: H.M.S.O., 1920) p. 19 . 
while one African represented Calabar township. Most of these appointed members were not native Nigerians: Chief O'Dwyer, who represented Calabar, was from Ghana; Sir Adeyemo Alakija came from Brazil and Justice S.B. Rhodes was a Sierra Leonian. Although Northern and Southern Nigeria were amalgamated, the Legislative Council failed to have African representation for the North and left Northern legislation in the hands of the British Commissioner.

The French, on the other hand, with their policy of cultural assimilation and direct colonial administration, absorbed most of the educated Africans. Leopold Senghor and Houphouet Boigny became members in the Chamber of Deputies. The French regarded the Africans as citizens of France and made the colonies as French provinces. Thus, the French transferred the African problems to metropolitan France, but the granting of independence to the former French colonies and the problems came back to those African territories. The civil war to suppress secession in Chad, the series of coup d'etats in Togo and Dahomey for example, failed to credit French acculturization.

In 1945 Sir Arthur Richards' Constitution balkanized the Colony and Protectorate of Nigeria into three regions: North, East and West. It set up Houses of Assembly with advisory powers in each of these regions. The constitution also established a Legislative Council for all the regions. This was 
really the first time that the two Southern regions were brought together with the North. The Richards Constitution was seriously criticized by the Nigerian intelligentsia who maintained that their own opinion was overridden by the British constitution makers. In 1950 at Ibadan a Constitutional Conference of representatives from all sections of Nigeria was held to review the Richards Constitution. The resulting 1951 Revised constitution created a central council of ministers and a House of Representatives for the whole country. It also provided for Regional Houses of Assembly and Houses of Chiefs in Northern and Western Nigeria. But the Revised Constitution was short lived. In 1953 in the House of Representatives at Lagos Chief Anthony Enahoro presented a motion that the House accept the attainment of self-government for Nigeria in 1956. Alhaji Ahmadu, Sardauna of Sokoto and leader of the Northern Peoples' Congress, moved the adoption of an amendment to change the fixed date to 'as soon as practicable'. Bitter debate on the amendment resulted. Members of the National Council of Nigerian Citizens and the Action Group Party walked out of the House. The members of the Northern Peoples' Congress were criticized and ridiculed as imperialistic stooges. On their return to the North they determined never again to be subjected to the Southern indignities; and they issued a statement of secession of the region from Nigeria. At the height of this tension, Chief S.L. Akintola of the Action Group scheduled a tour of the 
North to campaign for self-government in 1956. This led to four days of rioting in Kano in which about twenty-one southerners and fifteen Northerners vere killed. To forestall the Northern secession and to ease the North-South tension, a new constitutional conference held in London in 1953 decided that further discussions in Nigeria were necessary. In 1954 the meetings of the Constitutional Corference resumed at Lagos. The resulting constitutional document provided for direct elections to the House of Representatives. The regional legislatures were given increased autonomy and responsibility for specific matters. The granting of autonomy to the regions was a major turning point. It recognized that Nigeria could not be ruled under a single, centralized form of government, and that the amalgamation of 1914 as symbolized in the appointment of a single governor-general had been carried out for financial and economic reasons. In 1954 the only symbols of unity were the House of Representatives and the governor-general. The 10

Macpherson Constitution of 1954 decentralized political power in the country and accepted the fact that real diversities existed in Nigeria. The politicians in the country accepted the constitution and they acknowledged the differences in Nigeria.

10 John Stuart Macpherson was the governor-general of Nigeria (April 14, 1948-mid-1955) under whose chairmanship the constitution was written. 
The autonomous powers of the regional legislatures went into effect in 1957 when Eastern and Western Nigeria attained internal self-government. For two years the giant Northern Nigeria refused to follow this course because its leaders complained that there were inadequately trained men in its key administrative posts. In the northern and southern Cameroons, the former German colony given to Great Britain as a mandate and administered as part of Nigeria, there was some apprehension. The north, which was administered as a part of Northern Nigeria, decided to remain within Northern Nigeria, while the southern Cameroons, which was part of the Eastern region, accepted a quasi-territorial status and made plans for its independience outside the framework of Nigeria. In spite of its association with Nigeria from 1916 to 1958, the Southern Cameroons preferred to unite in 1961 with the former French mandated Cameroons, which gained independence in 1960. On October 1, 1960 the self-governing regions of the North, East, and West formed a federation. They adopted a national anthem symbolizing their common brotherhood. The Federation of Nigeria undertook a population census on May 13, 1962. The East had an average increase of 71 percent, although five of its census divisions had increases changing from 120 percent to 200 percent. The west showed a rise of over 70 percent, while the North had an increase of 30 percent. The chief Census Officer, Mr. Warren, dismissed these figures as too exaggarated. 
Before the census, there had been an active political campaign to register a substantial population since the number of representatives from each region to the Federal House of Representatives was to be based on the census. Surprisingly enough, during the population count the Eastern Regional Government announced the discovery of villages in Eket and Ibeno areas whose population had never been counted during the census of 1952. Other regions had justifiable misgivings that the census figures had been inflated. On November 5,1963 another census was taken under tense conditions and regional mistrust. While the census controversy was prevailing, an election to the Federal House of Representatives was held on December $30,1964$. 11

The United frogressive Grand Alliance with its core areas in the Eastern Region and Midwest boycotted this election on the grounds that many candidates were returned unopposed in the North. The resultant controversy precipitated a crisis in which the president of the country hesitated before announcing the appointment of the prime minister. The leader of the United

\section{1}

To prepare for the 1964 election the political parties in Nigeria reorganized by forming alliances. The United Progressive Grand Alliance comprises the National Council of Nigeria Citizens, which was the governing party in the East and the Midwest; the Northern Elements Progressive Union, which was the opposition party in the North; the United Midd]e Belt. Congress was also an opposition party in the North; and the Action Group, a governing party in the West until 1962 and an opposition party in the Federal House till 1965. 
Progressive Grand Alliance, Dr. Michael Okpara, felt that the Northern Peoples' Congress--the ruling party in the North and in the Federation--had undermined the unity of the country in many ways.

Between 1962 and 1965 events in Western Nigeria undermined the common brotherhood of the Federation. Western Nigeria faced an intratribal struggle of leadership and party conflict. Chief Obafemi Awolowo, founder and party leader of 13

the Action Group, and an opposition leader in the Federal House, dismissed his deputy Chier S.I. Akintola, premier of Western Nigeria for his failure to carry out party policies in his regional government. Chief Akintola and his supporters chose to form a new splinter party, the Nigerian National Democratic Party. At the same time, Chief Akintola refused to resign as the premier of the West on the grounds that he could only be dismissed from the premiership by a censure motion in the Western House of Assembly and the House of Chiefs. An attempt to move a censure motion in the Western House of Assembly

12

Chief Awolowo was the premier of Western Nigeria until 1959 when he joined the Federal House to lead the opposition; and chief. Akintola was appointed to lead the regional government.

13

The Action Group was a ruling party in the West, 195162, in opposition in the East, the Midwest 1951-62, and in the Federal House 1959-64. 
triggered a fight on the floor of the House. The Federal Gov14

ernment declared a state of emergency in the region and appointed an administrator, Dr. Moses Majakodemi. At this time a plot to overthrow the Federal Government was discovered; and Chief Awolowo, Joseph Tarka, who was the leader of the United Middle Belt Congress and other prominent members of the Action Group and its allies wexe accused of treasonable felony, and they were later jailed. Conditions of apparent normalcy returned to the West. Chief Akintola took the reins of government without any election to test his popularity since the normal term of the Western House had not run out. The governor of the region, Sir Adesiji Aderemi, who had not supported Akintola, was removed from office, and a new man was installed. On both regional and national levels the whole of 1965 was a power struggle in Nigeria anong the political parties. The Western House of Assembly was dissolved in 1965. Chief Akintola, with his party, formed an alliance with the Northern Peoples' Congress, while the Action Group allied itself with the National Council of Nigerian Citizens. During the election tension grew to a fever pitch. Balloting results showed chief Akintola as the winner, but his party was immediately charged with rigging the election. The leader of the Action Group

\section{4}

The Federal Government was run by a coalition of two parties: the Northern Peoples' Congress which ruled in the North, and the National Council of Nigerian Citizens which ruled in the East and in the Midwest. 
Alliance, Alhaji Adegbenro, occupied the State House only to be removed by the police. The loss of life and property in the rioting which followed the election was unprecedented, yet the Federal Government refused to intervene in the internal affairs of Western Nigeria.

The boycott of the national election by the United Progressive Grand Alliance and the election crisis in the West precipitated yet another crisis. This crisis seems to indicate that some elements in Nigeria had lost faith with the ruling elite in the country. On January 15, 1966, a group of young army officers staged a revolution. The premier of the North and leader of the Northern Peoples' Congress, Sir Ahmadu Bello, his deputy and prime minister of Nigeria, Sir Tafewa Belewa, the premier of Western Nigeria and leader of the Nigerian National Democratic Party, Chief S.L. Akintola, and the Federal Minister of Finance Chief Festus Okotie-Eboh were all assassinated. Nevertheless, the military spared some leading political figures from the purge--for example, the president of the Senate and acting president of the country, Dr. Nwafor Orizu, the premier of Eastern Nigeria and leader of the United Progressive Grand Alliance, Dr. Michael Okpara, and Chief Dennis Osadebay, the premier of the Midwest. Since Dr. Nnami. Azikiwe, the President of the country was away on sick leave, the acting President, who was the highest ranking civilian official, presumably intimidated by the military coup, failed 
to appoint an acting Prime Minister. The Federal Parliament was still in session, and it too, through the cabinet, failed to appoint a civilian leader. Perhaps out of fear or for political reasons, the Federal Cabinet, presided over by Alhaji Zanna Bukax Dipcharima, decided to hand over the government to the army and the police. With the Acting President's announcement of this decision to the nation, the military coup d'etat successfully removed the civilian government and suspended the operating framework of British democracy.

The Supreme Commander of the Nigerian Armed Forces, Major-General Ironsi assumed control of government and suspended the Civil Constitution. By his own instrument of power, he annulled the federal structure and instituted a unitary form of government such as the civilians had tried with the 1951 Revised Constitution. The Unification Decree Number 34, which was issued on May 24, 1966 caused a reaction in the North where fear of Southern domination was strong. On May 29, 1966, some Northerners took to violence. Some Southerners were murdered, especially people from the East who lived in Sabon-Gari. Escapees fled to their homelands. This violence against the Easterners was probably due to the fact that Major-General

15 On the fringes of northern citjes there are strangers' quarters; and the largest Sabon-Gari is in Kano. 
Ironsi and most of his advisers came from the East. It can also be regarded as a reaction against the assassination of their tribal leaders. The North always had been a barometer indicating the tempo of the country's socio-political progress and the violence there was probably an attempt to thwart the MajorGeneral's plans for a unitary state.

As if the violence of some Northerners was not enough to forestall the newly announced program of the Major-General, on July 29, 1966 certain elements in the army undertook a coup d'etat. Major-General Ironsi, and the military governor of the West, Lieut.-Colonel Adekunle Fajuyi were murdered at Ibadan. On August 1, 1966 Lieut.-Colonel Yakubu Gowon from the Middle Belt in the North assumed the supreme comnand of the Nigerian Armed Forces and became head of the Federal Military government. Within the Nigerian army itself there was no unity; and it faced both a leadership struggle and the delicate task of determining the type of government by which the country was to be ruled. The head of the Federal Military Government, MajorGeneral Yakubu Gowon, restored the federal structure of government. Furthermore, he released from prison Chiefs obafemi Awolowo, Anthony Enahoro, Efiong okon Eyo and other politicians who had been jailed for treasonable felony and conspiracy by the earlier civilian government.

The lack of unity in the army became increasingly obvious when the military governor of the East, Lieut.-Colonel Chuk- 
wuemeka ojukwu wanted a type of government that would provide greater security and protection to the life and property of the Easterners. The May violence in the North and the July coup within the Nigerian army caused him to believe that the Federal Military Government, as constituted, was incapable of protecting the people of the East. He felt, perhaps, that the East was a homogeneous state whose cause he could champion and thus determine its own destiny. He ordered all Easterners who were residing in other parts of the country to return to the East. The East gained in population but in doing so put great 16 pressure on its limited space and economy. On May 27, 1967 the Federal Military Government created twelve states, three 17 of which were carved from the Eastern region. The long sought for objective of minorities in the country was thus realized. Lieut.-Colonel ojukwu was thus denied the leadership of the whole East. Committed to the principle that the East was a homogeneous unit and insisting on championing its self-determination regardless of the minorities' feelings, Lieut.-Colonel

\section{6}

The landspace of the East was 29,484 square miles with a population of 12.4 million; and the more fertile areas are the fringes toward the southeast. Toward the southwest fringe are the creeks and oil wells. On the northern fringe is the coal field. The oil wells and the coal field are Federal Government property leased to companies and corporations.

17

The three states are the East Central, the Rivers, and the South-Eastern. 
ojukwu declared his territory the Republic of Biafra and announced its secession from the Federal Republic of Nigeria on May 30, 1967. On July 7, 1967 the Federal troops invaded Biafra, concentrating their attention to the minority areas-the Rivers and the South-Eastern States--which fell to the Federal forces during the early part of the civil War. There was no doubt that some minorities supported Biafra, but it is clear that a great many of them raliied around the Federal Military Government. Self-determination of the minorities was a basjc principle within the federation and this was granted them. The former civilian government had ignored the claims of the minorities.

During the early part of the Civil War the Biafran forces undertook an expansionist strategy instead of defending the territorial area of the former Eastern region. Between August and September 1967 the battle moved into the Midwest region which had been carved out of the western region in 1963 . The Biafran forces occupied the Midwest and declared it the Republic of Benin, but towards the end of September, the over-extended Biafran troops were chased out of the Republic of Benin. The occupation of the Midwest probably was undertaken in part

\section{8}

In 1958 the Willink Commission set up solely for minority affairs reported that the fears of minorities exist in Nigeria, but it refused the creation of more states and, rather, recommended the Rivers area as a specialized region for development by the Federal Government. 
because Ojukwu wanted to offer protection and security to the Western Ibos--some members of Ojukwu's ethnic group who were cut off from those of the Eastern Region--and partly because the oil wealth of the Midwest would supply badly needed revenue for the war efforts.

In time economic blockade and loss of food producing areas produced increasing starvation among the Biafrans. With the aid of an obliging foreign press Major-General Ojukwu aroused the conscience of the world. This support helped keep Biafra alive and thus sustained the war for over two years. The Republic of Biafra gained international recognition from Tanzania, Zambia, Gabon, Ivory Coast and Haiti. The recognition of Biafra was done either to put pressure on the Federal 19 Military Government to accept peace moves, or to give moral support to the besieged Biafra and thus embarrass the Federal Military Government. But all peace mediation efforts failed to end the conflict. Major-General Ojukwu won the propaganda warfare particularly by his charge of "genocide", but the Federal forces ultimately had their victory on the battlefield. On January 11, 1970 General Ojukwu fled Biafra; he left the leadership to Major-General Philip Effiong, the Chief of the General Staff, who capitulated on January 15, 1970. After thirty months

\section{9}

There were peace talks at Niamoey in Niger, Kampala in Uganda, and Addis Ababa in Ethiopia. There were also peace moves by the Commonwealth secretary and by the organization of African Unity. 
the biafranization of Nigeria came to a tragic end. Even though fighting for self-determination is at present going on in chad and in the Sudan, the collapse of Biafra suggests that such efforts are doomed to little success in this era. The support of 20

members of the Organization of African Unity for a united Nigeria portrays that the majority of the African nations do not wish the readjustment of the artificial boundaries of their countries.

20

Tanzania, Gabon, Zambia and Ivory Coast, all members of the O.A.U., supported Biafra. But it is doubtful if they would support balkanization of their own countries. 


\section{CHAPTER III}

\section{THE PROBLEMS OF UNITY}

In the context of the foregoing discussion, we must examine the powerful centrifugal forces at work in Nigeria and consider to what extent they are due to the actions of Great Britain as the colonizing power. From its inception, Nigeria was arbitrarily carved out from the various existing empires, states and kingdoms. Part of the great empire of Kanem-Bornu was within the present borders of Nigeria. It also extended into present Niger and Chad, both formerly French colonies. The Fulani empire, which also extended into Niger, ruled most of the cattle and grain raising lands of the North before its conquest in 1906 by the British government. The subjects of Kanem-Bornu empire recognized El-Kanemi or the Shehu of Bornu as their leader; while in the Fulani empire the Sultan of Sokoto was regarded as the overlord. Within both of these empires lesser lords--emirs-ruled in each of the emj.rates.

$$
1
$$

Kanem was east of Iuake Chad while Bornu was west of the lake. The empire was built around the lake; and it might have shifted its capitol in course of time.

2.

The Fulani empire was originally the 14 Hansa states which were later conquered by the Fulani who became the overlords. 
These two empires covered much of the grassland and semi-desert of Northern Nigeria. From their topographical condition, rolling plain, these empires had every reason to cover an extensive area. The peoples of these empires took to cattle raising, moving from pasture to pasture. This nomadic life is still practiced by the Cow Fulani. Aside from cattle herding tiney undertook caravan trade in salt and leather. Thus, to all intents and purposes most of the people were nomads; and their empire and jurisdiction of their ruler had taken into account the conditions of nomadic life. In addition, there were those people who settled in towns such as the settied Fulani. Perhaps Lord lugard got his first experience of native rule from them. Nevertheless, the Caravar: trade dominated every aspect of life of these peoples and linked much of the territories of the empires to North Africa. By 1885 Sir George Taubman Goldie's trading firm, the United Africa Company, dispatched its deputy, Joseph Thompson, to Sokoto. In an attempt to control the caravan trade Joseph Thompson signed a treaty of trade and jurisdiction with the Sultan of Sokoto. Thus he secured this vast empire for the British. An attempt was henceforth made to divert the

3

The United Africa Company was a combination of all British firms as they were advised by Goldie. Within a short time the company bought off the rival French trading firms and thus it became the Royal Niger Company in 1886, whose spheres of influence covered much of Northern Nigeria. 
Northern trade to the southern coast. This diversion of trade notwithstanding, the north has preserved something of the North African outlook with its own distinction as an ancient feudal empire.

Aside from the savannah empires of the North, there was the forest kingdom of Benin in the South. The quality of Benin's arts is widely recognized and the trade of Benin had attracted the Portuguese from the earliest period of contact. Benin developed culturally and commercially while its ruler-the Oba of Benin--became an absolute monarch, especially in spiritual affairs. The people of Benin indulged in human sacrifice to ward off any nisfortune. They also look to warfare for territorial expansion and booty. These actions of the Oba and his subjects alarmed the agents of the Niger Coast Protectorate who in 1897 sent an emissary to Benin. The envoy was denied entry into Benin, and a British force was called ir. Although Benin was partially destroyed and oba Overami was 4 captured, the ancient greatness of Benin is a source of pride to the Binis.

Along the Guj.nea Coast was the Yoruba empire which took most of Dahomey, a former French colony. In secular affairs the empire was administered from Oyo, while the spiritual headquarters was at Ile Ife. Within the empire was the separate

\section{Oba Overami was deposed and exiled to Calabar. He died} in 1923 .

Alafin of oyo is a title given to the ruler, while oni relates to the ruler of Ife, and Alake to that of Abeokuta. 
Egba kingdom with its Alake of Abeokuta. The autonomy of Egbaland was retained until 193.4 when a treaty recognizing its independence was annulled and Indirect Rule was substituted. The Yoruba people did not stay in situ. Either as a result of their simple economy or as a result of intra-tribal wars the Yoruba continued to found city-states such as ondo, Ijebu, Ibadan, Abeokuta, and Ilorin though the latter was conquered and occupied by the Fulani in 1831. The internecine struggles of the Yoruba people led to the disintegration of the empire, but the Yoruba cuj.ture remains one of the most sophisticated in Nigeria.

The European demand for slaves and paln oil allowed the growth of some city-states on the Niger delta. King Jaja of Opobo, King Pepple of Bonny and Nana of Istekiri, who interfered with European penetration and trade expansion were removed and deported by the British Consul. However, these city-states formed the nuclei of the new towns occupied by some minorities of the Niger Delta. Their demand for a separate state within the federation was a part of the irredentist movement that colored the politics of the regional based civilian government.

In addition to the city-states and the empires already mentioned there were Nupe and Jukun kingdom of Kwarafa, as well as the kingdom of Idah which may have been an offshoot of the Jukun. The territorial areas of these ancient kingdoms are at

6

King Pepple was deposed and exiled in 1854 but he was restored in 1861. Ring Jaja was deported in 1887, while Chief Nana was removed in 1894 . 
present settled by some of the minority tribes of the Middle Belt of Northern Nigeria, that is, those groups which during the last civilian government demanded the creation of the Middle Belt State. The Hausa states of Gobir, Katsina, Daura, Kano; Zazzau (Zaria) Yauri, Kebbi and Zamfara were defeated by the Fulani Jihad of 1804. The Hausa and the Fulani developed a common culture and they present a homogeneity which is in contrast to what prevails elsewhere in Nigeria. of course, within this homogeneity, Kano, a metropolis with highly sophisticated culture refused to be regarded as a fief of the sardauna of sokoto. It continued its defiance by demanding a separate Kano state; and it admitted withjn its emirate a political party based in the South.

It should be observed that some of these ancient empires, city-states and kingdoms contain peoples who are still occupying their traditional territories. The Yorubas in Yorubaland, the Binis (Edos) in Benin, the Nupes in Nupe kingdom, the Kanuris in Bornu, and the Hausa-Fulani jn the Fulani empire are all rooted into the areas of their ancient states. They remain attached to their own glorious past instead of identifying with Nigeria as a country. This land and people concept has significant effects on social mobility, otherwise a great stimulus towards national unity. A member of another tribe who moves into a non-traditional homeland is regarded as a stranger who should live in Sabon-Gari. Although the lack of common historical identity contributes to the absence of unity, it is really the relationship of the people within these ancient 
city-states and empires with the central government that affects national unity.

Some other African governments with similar problems have undertaken different measures to forge national unity. The Gold Coast, a former British colony, changed its name to Ghana, an ancient empire within the present area of the country. But the ancient empire of Ghana did not extend to the northern part of the Gold Coast which was a part of the Ashanti empire. The Ashanti people in the northern territory showed a separatist tendency but it was minimized by the one-party system in Ghana and the dictatorial rule of ex-President Nkrumah. The French Sudan assumed the ancient name of Mali empire by joining with Senegal in 1959-61 in the Mali Federation. One might have hoped for the success of the Mali Federation since Senegal had been part of the Mali empire, and it had shared a common French colonial history and administration. In spite of such elements of common identity the Mali federation failed because the Senegalese felt that the union was dominated by the Sudanese. Above all, there was opposition to the federation by France and the Ivory coast. On the other hand, Uganda got its independence with live-kingdoms of Bunyoro, Ankole, Karagwe and Buganda within its borders. The British had not wanted to destroy these kingdoms as long as the kings and their subjects were loyal to the British monarch. But to foster national consciousness the president of Uganda, Milton obote, drove into exile the last strong king of Buganda, Kabbak II. He disbanded the Kabbaka's 
private army and he dissolved the king's parliament. Milton Obote undertook the dissolution of the live-kingdoms within his country. At present, it is too soon to accord full success to Obote's programme of national unity. Nevertheless, it is clear that the memory of, or continued existence of ancient kingdoms within some African countries has caused problems of national coalescence and has been the source of much discord with the central government.

Within the artificial creation of Nigeria, a conglomerate of ancient empires and city-states, live 250 officially recognized ethnic groups with variations in tradition, culture, language, loyalty and religion. It may be of interest to give a cross-section of distinctive traditions and customs in the country. The traditional kingdom of Benin, now the Midwest State, and the Fulani empire of the north will be examined: A Bini deciding to become a christian. Such a
decision is not only the concern of the individual;
it has repercussions on the wider family, especially
if the person... is the head of one of Benin's extended
family groups... Ancestor worship is stily deeply
rooted in the daily routine of the Bini... The Fu-
lani... if he is a follower of Islam--fond of his Ko-
ran.... Many Fulani are however Pagan, with no marked
tendencies for Islam but working out a life guided
by instinct, superstition and animism.
quickly vacate an area where one of their people dieg 7

Federal Ministry of Information, Nigeria 1960 A Special Independent Issue of Nigeria Magazine, October 1960. (Federal Government Printer, Lagos, Nigeria, 1960) p. 163.

8 Ibid. pp. 184-85 
Within Nigeria there is accordingly no common tradition and culture on which modern nationalism could be based. The lack of unity of culture and tradition characteristic of Nigerian society as a whole is even more pronounced among the elite who lead the country. The European Powers introduced into African society their standards of value and modes of life, mainly in the cities. The Africans in these urban centers have copied this European culture and sometimes they seem to become more Europeanized than the Europeans themselves. Progress towards civilization is even measured by how much of European culture these westemized Africans could adopt. But the imported culture fails to spread evenly and to dominate the country. The failure of the western oriented culture to replace fully native cultural traditions, or perhaps the failure of the two cultures to produce a workable almagam, affects the stability of the country.

Likewise great variation in religious beliefs has been detrimental to the unity of Nigeria. Between the eleventh and twelfth centuries, Islam expanded rapidly into North Africa and the western Sudan. During the early part of the nineteenth century the Furopean powers were looking for spheres of influence by means of geographical discovery and legitimate trade in Africa; and a revival of Islam expansion through holy wars of jihads took place in Northern Nigeria. Uthman dan Fodio of the Fulani tribe became the leader of this reforming and

The late Ahmadu Bello, the Sarduana of Sokoto and premier of Northern Nigeria was the grandson. 
expansionistic Islamic movement. He appointed the fourteen flag bearers who spread the jihad with burning zeal in Northern Nigeria. Although the jihad was halted in Bornu by Mohammed el-Kanemi, the spread of Islam filtered in through the Fulani traders and herdsmen. Northern Nigeria became not only Islanized but also Fulanized for the Fulani, having conquered Northern Nigeria, became the ruling class over other inhabitants. The spread of Islam and Fulani overlordship penetrated the Yoruba state of Ilorin. Before the death of Uthman dan Fodio in 1817, much of Northern Nigeria was greatly influenced by Arabic-Islam imperialism.

While the jihad spread in the North, the European traders and missionaries established stations in the South. By 1836, the Church Missionary Society gained influence in Abeokuta in Yorubaland. Between 1841 and 1852 the Church Missionary Society and the Wesleyan Methodists were very active sowing seeds of European religious imperialism in Lagos, Badagry and much of Yorubaland in Western Nigeria. By 1846 the Church Missionary Society crossed the Niger into the East and opened a station at Calabar. In 1886 the Irish Catholic Missionaries undertook evangelization in Onitsha in Iboland. During the early part of the nineteenth century the South moved towards European religious values and the North embraced the Islamic culture.

There is another. interesting aspect concerning the geographic distribution of religious beliefs in Nigeria. BY 1900, when Lord Lugard became the high commissioner of the North, he 
supported the treaty of the Royal Niger Company which did not allow Christian missionaries to penetrate into the Muslim North, unless such missionaries were invited by the emirs. The Christian missionaries were encouraged to evangelize in the pagan Middle Belt of the North. Between 1903 and 1905 the Church Missionary Society was invited by the emirs of Bida and zaria to open Christian stations in their emirates. Thus within the North there are pockets of Christians as there are of pagans. In the South, likewise, there are enclaves of paganism and Islam. When the population of Nigeria is examined, about 44 percent of the people are Moslems, while 22 percent are christians. The remainder stick to their traditional cults. But when the geographical distribution of religion is examined, the North is two-thirds Moslem, while the South is Christian and pagan.

The North as an Islamic bloc detaches the region from the country and tends to link itself with the Arab world and other African Islamic countries. It may be of interest to point out that the late Sarduana of Sokoto, Premier of Northern Nigeria, Vice-President of the World Islamic Congress and President General of the Northern Peoples' Congress, denied the government of Israel participation in a fishing industry in Lake Chad, despite the fact that the development program was offered by Israel to the Federal Government. The civilian government was forced to respect such a geographical ban since Lake Chad is within the jurisdiction of the North. But the ban 
of Israel in the North was embarassing to other regional and Federal Governments which maintained cordial relations with the Israeli government. Thus the religious divisions in Nigeria complicate foreign relations of the country and endanger the unity of the federation.

In the christian South, especially in the East, denominational differences sometimes flare up as when in 1965 catholics opposed the East Regional Government's plan to take over education. During the Civil War 1967-69 the Biafrans believed that they were fighting a war against the Moslem North and therefore they appealed to all the christian countries of the world for aid to restrain Islamic advancement at the expense of the Christian East. Since the East was two-thirds Catholic, many people of the catholic faith readily accepted humanitarian arguments regarding the necessity of keeping Biafra alive, and thus, wittingly or unwittingly, aided an attempt to dismember the Federation. It is easy to conclude that religious loyalty is very strong in Nigeria and stands in the way of national unity.

For comparative purposes, sudan, the former Anglo-Egyptian Sudan, also presents a case of disunity arising from the distribution of religious beliefs. A civil war seldom mentioned in the world press is going on between the North and the South. In the North the people are mostly Moslems and of Arabic culture. In the south some people are christians while others practice their traditional beliefs. The Southerners also feel that they have African consciousness. At present the south is 
rebelling against the Moselm-Arab-culture dominated government of the North. It is true that cultural variation plays a part in sudanese disunity, but the control of government by the Moslem North suggests that emphasis must be put on religious differences. During the era of British administration, Moslem preachers met restrictions in the South while christian missionaries were encouraged. Arabic language and influences 10 were also restricted in the South. But with Sudanese independence the Moslem-dominated government tried to Arabicize education and it aroused more resentment from the South. It is true that the Arabisation of education would have contributed towards national consciousness, but at the same time, it may be regarded as cultural and religious imperialism. It is possible to blame the British administration for its restriction of Moslem proselytes in the South and thus failure to press for an integration. Since the Moslem-dominated government failed to adopt a federal constitution as advocated by the Sudan African National Union, one of the oldest political parties in the South, not all blame can be laid at the feet of the imperial powers. The Anya Nya--guerrilla fighters--have taken to the forest to fight and liberate the south. Another case in point of religious differences as a factor of unity is that of Ethiopia, the oldest independent

10

George W. Shepherd, Jr. "National Integration and the Southern Sudan." The Journal of Modern African Studies Vol.4: 2. p. 200 . 
kingdom in Africa. By 1833 Italy entered the eastern sector of Ethiopia and occupied what came to be called Eritrea. In 1889 Italy and Ethiopia signed a treaty to define the boundary of Eritrea. Italy was not satisfied with Eritrea and in its attempt to occupy other areas of Ethiopia, Italy fought the battle of Adowa in 1896 in which it was defeated. In spite of the Italian defeat it still maintained Eritrea. After the Second World War Eritrea was given as a trust territory to Ethiopia; but in 1952 Exitrea was joined to Ethiopia after a plebiscite. In Ethiopia, from very ancient times, most of the people are Ethiopian Orthodox Christians. Within Eritrea, the Tigreans are Ethiopian Orthodox; along the coast, the Afar and the Danakil are Moslems. At present the Eritrean Moslems are pursuing a liberation movement which endengers the unity of Ethiopia. It may be remarked in passing that if the Eritrean Liberation Movement and the Sudanese African Liberation union succeed, Afro-Arab unity in African countries may well be endangered.

Where there is a large concentration of some religious belief, even if the believers were formerly ruled by two different colonial administrations, national unity can be attained rather easily. Italian Somaliland and British Somalia were colonized by two different European powers. But there is a large concentration of Moslems in both countries. There is the same Arab culture and language. British Somalia was granted independence in 1960 and within the year Italian Somaliland 
gained its freedom. On July 1, 1960, without much fanfare, the two national assemblies formed an independent Republic of Somalia. At present there is the French Somaliland outside the Republic, and there are some somalis in the northern provinces of Kenya, the Haud and Ogaden regions of Ethiopia. Pan Somalia. may be the next alternative although such option may result in conflict with the neighboring countries. However, the national consciousness of Somalia is only delayed by differing colonial administrations.

Nationai consciousness may also be developed where religious beliefs are evenly spread out. (Of course there may be other factors such as the consensus of opinion of the national leaders.) Tanganyika and the island of Zanzibar were former German colonies which after the First World War were given to Great Britain as Trust territories. There are pagans, Moslems and Christians in both countries. In 1961 the mainland of Tanganyika was granted independence; and in 1963 zanzibar was decolonized. In 1964 the two heads of state agreed to unify the two independent countries into the Republic of Tanzania. of course national unity may be achieved in spite of differing religious beliefs. The idea of a common empire history well directed by the national leaders, for example, may activate national consciousness. Such a case of national unity achieved despite religious diversity is that of the two cameroons. Northern and Southern Cameroons were former German colonies which had been administered as one country. After 
the First Wor1d War, Northern Cameroon was divided into two sections. The western part, close to Nigeria, was given to Great Britain as a trusi territory; and it was administered as a part of Northern Nigeria. A plebiscite conducted in 1961 allowed this section of the northern Camercons to be integrated with Nigeria, and it was named the Sardauna Province. The east sector of the Northern Cameroons was administered by France as a trust territory. The Southern Cameroons were administered as a trust territory and as an administrative part of Eastern Nigeria. Between 1957 and 1950 the Southern Cameroons became a quasi-territory. An 1961, after the independence of Nigeria, a plebiscite was held in the Southern cameroon and it decided to join the former French trust territory of Northern Cameroon, which had received its independence in 1960. Within the Northern Cameroon, now Eastern Cameroon, Moslems predominate with some Christians and pagans; while in the Southern Cameroon, now Western Cameroon, Christians predominate, but there are pagans and only very few Moslems. Despite a mixed distribution of religjous beliefs and a past history of subjection to two colonial powers, the two Cameroons-Western and Eastern--have formed a united republic. However, in this case both terxitories had shared a common German colonial background; the memory of this, perhaps, gave the inhabitants grounds for believing that the French and the British had willfully divided them. The unification of the two cameroons, despite different religious faiths, language, colonial 
administrations, culture, and above all, ethnic groups, is a challenge to other African countries that all too easily blame European powers for their internal disunity.

National unity is not necessarily created on the basis of a common religious belief. Once again Nigeria supplies an illustration of this condition. Within Northern Nigeria, twothirds of the people are Moslems. Thus in nearly all the emirates, with the exception of the Midale Belt area, there is a concentration of Islamic adherents who should hold together. But in the last civilian government the Kano emirate failed to support the regional secular and spiritual leader. Alhaji Aminu Kano based the Nigerian Elements Progressive Union in Kano as an opposition party to the Northern regional government. A Southern-based political party--the Action Group-was allowed to campaign in Kano during the 1959 Federal election. Along with the Middle Belt, Kano demanded a separate state in an attempt to subdivide the northern region. In 1953, the first riot between the northerners and the southerners took place in Kano city; and in 1966 the massacre of some people of Eastern Nigerian origin also occurred in the city. A close examination of the composition of the population of Kano emirate shows a large concentration of Hausas who were the overlords of Northern Nigeria until conquered by the Fulani during the Jihad in 1803. Although the Fulani subsequently adopted the Hausa language, there seems to be resentment wherever Hausa consciousness remains strong. Furthermore, 
Kano City is the most sophisticated city in the North. It has the largest Sabon Gari on its outskirts. It is an old caravan trade center and a modern commercial place. Since the construction of its international airport it has become the greatest metropolis of the North. The special characteristics of Kano strongly suggest that growing sophistication weakens the support of traditional religion as a unifying force.

With the exception of Northern Nigeria, where Hausa is widely spoken, each ethnic group in Nigeria has its own language. In many cases the only common language is English. Even though English is the official language of Nigeria, it is not the lingua franca of the ilji.terate masses. This impedes the communication and dissemiration of political ideas both within the regions and across regional and tribal lines. The country as such is divided into language blocs. Nevertheless, the use of English as a common medium of expression by the educated Nigerians has produced national consciousness within that group. Perhaps, if during the sixty years of British occupation of the country the colonial administration had aimed at cultural imperialism and seriously tried to spread English culture throughout the country, national unity would not now be plagued by some of its present problems. But, of course, the British would have been accused of destroying the native language and culture, and of trying to turn Africans into Englishmen. The failure of cultural assimilation as a unifying force can be especially well examined in the former French West 
Africa, comprising Senegal, Sudan, Mauretania, Upper Volta, Niger, Guinea, Ivory Coast and Dahomey. Between 1902 and 1904 French laws allowed these colonies to be grouped and administered as a unit with headquarters at Dakar in Senegal. Fortunately there was no other European colony that intervened disruptively. To be sure, the former British colonies in West Africa were interspersed among the French territories, but French West Africa constituted a bloc extending from the coast inland to join other French colonies of North Africa. The French system of direct administration refused to recognize African life and the colonial administrators worked hard to make Frenchmen out of the Africans under their control. African children were taught French and French culture. The entirety of French West Africa received one language and culture; as a result, one might have thought French West Africa 11 would have maintained its unity after independence. Yet independence was no sooner granted to each of the countries than the federalized structure collapsed. Apparently, French West Africa was only a house of cards held together by French pres-

\section{1}

In September 1958 President Charles de Gaulle offered the colonies a chance to hold a referendum so that they could choose between becoming self-governing republics within a French community and complete independence. Member colonies of French West Africa and Equatorial Africa voted to remain as republics, but Guinea, a member of French West Africa, voted for complete independence. In 1959 senegal and Sudan formed the Mali federation and demanded complete independence. Shortly thereafter other members demanded complete independence; the French community went defunct. The Mali Federation was dismantled. French West Africa and Equatorial Africa became fragmented. 
ence. The French language and culture seem to have been successfully imposed on the younger generation, but the older generation, important sustairing factors of tradition and stability, were left out. It seems clear that African life continued beneath the French superstructure. The elements of unity introduced by the French in French West Africa did not suffice to produce a lasting national consciousness in the face of the continuity of native African differences.

There is yet another centrifugal force working against national unity in Nigeria and elsewhere in Africa. Some tribal groups cross regional lines within Nigeria with the result that a given people may be divided under two different political administrations; for examole, the Yoruba in Ilorin, a part of Northern Nigeria and the bulk of Yoruba in the Western region, and the Ibo in Eastern region and a part in the Midwest. All these peoples had been settled in the different areas for a very long time, but in more recent times Ibos migrated to the North. The September Massacre in 1966 confirmed the weakness of Nigerian unity when confronted by social and tribal or regional tensions. The effect of long-standing cross-regional settlement can be observed in the Nigerian civil war in which the Ibos of the Republic of Biafra (Eastern Region) were in league with the Ibos of the Republic of Benin (Midiwest). cross-regional settlement of ethnic groups in Nigeria is the

\section{2}

Some Ibos were murdered in the North. 
cause of much friction. Perhaps the present creation of more states where some tribes are given states of their own will minimize the friction.

It may also be remarked that some of the tribal groups run across international boundaries so that there are the Yorubas in Dahomey, and the Hausas and Fulani in Niger and the Cameroons. The problem of cross-regional ties then can have international implications. For instance, the Action Group party which governed the bulk of the Yoruba in Western region suggested in $i 960$ the incorporation of the Yorubas of Dahomey as the fourth region in Nigeria, and the Dahomeyan 13

Yorubas raceived the idea favorably. This suggests quite clearly that some Nigerjan trjbes think of territorial aggiandizenent which is likely to be a source of conflict and political disunity.

Nigeria is not the only nation in Africa where tribal groups run across international boundaries. There are Somali communities in eastern Ethiopia, in the northern district of Kenya and in French Somaliland, although the bulk of the Somali. Iive in the Republic of Sornalia. The Masai people are located in Kenya and in Tanzania. In Morocco, Ifni, Rio de Oro, Algeria, Tunisia, Libya and Mauretania there are Berbers and Bedouin tribesmen. As a result of such patterns of mixed settlement, some African countries have quarrelled and fought

\section{3}

I. William Zartman, "The Politics of Boundaries in North and West Africa," The Journal of Modern African Studies. (Cambridge University Press, 1965) Vol. 3:2, p. 170. 
about their frontiers. Algeria and Morocco, Ethiopia and Somalia, Kenya and Somalia, Ghana and Togo, just to name a few, have all faced border disputes arising from the geographic spread of a people. This division of a people between two or three countries has frequently been blaned on the European powers, that is African countries are said to have been artificially created without regard to the African feelings. However, the European powers which colonized Africa should not receive all of the blame. The Bedouin, the Masai and the Hausa-Fulani are nomadic herdsmen and caravan traders. The traditional African economy of sedentary agriculture and cattle herding moved some of the African tribesmen away from their traditional homelands; they could not multiply and stay in situ. To some of the tribes the homeland was wherever food and good pasture could be obtained, or perhaps where a profitable market could be located. Their boundaries of a tribal unit followed a seasonal moving frontier; they did not define themselves within any fixed 'state'. The geographically conditioned mobility of some African tribes fragmented them as 14

semi-stateless people, though of course it did not destroy their sense of totem and the sense of belonging to a tribe.

In some cases it was not the European powers which divided a truly unified ethnic group. For instance, the king-

14 limitation.

It does not mean anarch but it means lack of boundary 
äoms of Buganda, Bunyoro, Ankole and Karagwe were tied together to become economically and politicaliy viable. African society was fluid; some tribes such as the Yoruba had a past history of intra-tribal quarrels and wars. As a result of such quarrels and intra-tribal wars, there were offshoots of a tribal group which settled outside the ancestral home area under a new leadership. For instance, Abeokuta in Egbaland was fourded in 1830 by Yoruba refugees from lbadan. They called themselves the Egbas even though a branch of the Yoruba people. The spread of the Yorubas and some other African tribes was due to wars or disobedience to their tribal leader who might then force them to found a new homeland outside the territorial area.

Another factor of great importance which transferred some African tribes to other areas and thus encouraged the easy breakthrough of artificial koundaries by the European powers was the internal slave trade as well as the slave trade across the Sahaza Desert, both of which had existed before the advent of the European powers. Constant warfare for slave raids caused waves of migration of people to well protected 15 areas. In the former Eastern region there are the Eastern Ibibio Ikono people in Anang province while the bulk of Ibibio

.15

Migration of people occurred in historic times in Africa. It might have been caused by demand for food and land hunger, by flood, by superstitious beliefs, by trade and by a desire for protection against an aggressive neighbor. 
people live in Jyo province. The wars instigated by the European powers themselves in their efforts to subjugate certain areas a.lso caused waves of migration, for example the French war with Futa Toro State in 1817, Faidherbe conflict with alHaji Umax in 1857, and the Fulani war with Britain between 1901 and 1906.

When the European powers had once established fixed boundaries for their colonial possessions, some African tribes that had moved away from their homeland were no longer able to return. Most of the European administrators were not experts in anthropology and sociology and aid not understand the tribal cultures and lineage. A great many of the administrators were soldiers sent as officials, often as a result of governmental patronage; and what interested them was strict discipline. They insisted on forcing some of the nomadic African tribes to settle against their will. Most of the European administrators did not know the language of the tribal states in which they worked. Guided by the sense of a "mission" of representing a higher civilization the agents of the European powers decided on what was good enough for the Africans. It was not that the Africans had no states but such states did not limit the movement of people outside the frontier. The state was the influence of a recognized ruler along with the loyalty of the subjects. Thus the application of the European idea of a state to African tribes ignored the African modes of life which were in conformity with their basic economy. 
It may be remarked that some European powers, for instance Great Britain, after it had claimed Nigeria, did try to trace the lineage of some tribes and to regroup them. Becween 1920 and 1930 the British made a survey of the various totems of groups of people mainly in the Eastern provinces where a strongly organized indigenous government covering a large area was non-existent. Wherever the totems were identicai these people were grouped under the same clan with a clan council and a paramount chief. It might be argued that such regrouping came late and of course did not bring into one fold those people of the same totem who lived either in the French or the German territories. The primary purpose of this reorganization was not to re-settle the 'nomadic! tribesmen of the area for their own good, but to make it easy for the administrators to supervise them. Even so, it was a step in the right direction. The people needed a sense of a large core area as an element of governmental jurisdiction. of course this structure of administrative units covering extensive areas presents another problem for national unity.

The problem of enclaves of minorities within regions dominated by a powerful tribe that is in the majority exists for many African countries. In Kenya there are the Kikuyu who are in the majority, and the Luo, the Masai, the Kipsigis and the Gusii who are minorities. In Uganda, the Bakanda are in the majority while the Teso, the Acholi, the Banyoro and the Ganda are all minorities. 
In Northern Nigeria the Hausas are $5 \frac{1}{2}$ million, the Fulani

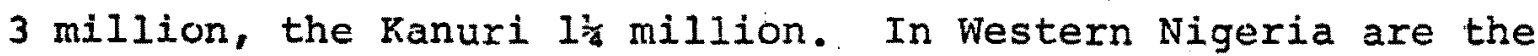
Yorubas $4 \frac{1}{2}$ million; the Edo 452,000; the Western Ibo 374,000 and the Urhobo 346,000 , though at present the last three named tribes are in the Midwest state. In East Nigeria there are the Ibo 4 million, the Ibibio 750,000, the Annang 450,000 and 16 the Ijaw 265,000. The dominant tribes obtained control of political power in each such region; the policy of regional government became a source of tribal rivalry and aroused constant fear in the minorities. Between 1957 and 1958 the Minorities Commission was appointed. The Willink Commission admitted that there were fears of tribal domination and discrimination. But the Willink Commission was strongly against the creation of new states in Nigeria, even though in most of the minority areas there were movements favoring separate 17 statehood such as the Middle Belt, the Benin Delta and the Calabar-Ogoja-Rivers states. In 1943 Dr. Nnamdi Azikiwe, then leader of the National Council of Nigerian Citizens, and later the Governor-General and President of Nigeria, had suggested the regrouping of Nigeria into eight political administrative units. In 1953 Chief Obafemi Awolowo, the leader of the Action Group and later the Premier of Western Nigeria wanted a division of Nigeria into nine states. But in 2957

\section{p. 13. \\ 16 Nigeria Year Book 1964 (Times Press Limited, Lagos)}

\section{7} The name was changed to the Midwest State, which was the only state created out of the Western Region in 1963. 
Dr. Azikiwe in a speech at Ana opposed the creation of new states at the expense of Eastern Nigeria. The colonial government, on the other hand, feit that not more than one new state should be created from each region and that it must be economis

ically and politically viable. Nestern Nigeria agreed to the principle of permitting the eeparation of mirorities by creating of new states, not only in the West but in other regions as well. The North and the East opposed the bulkanization of their regions. British government was paralysed in its efforts to cater to the self-determination of the minorities and left them to the mercy of the majority tribes. But Her Majesty's Government saw to it that constitutional guarantees were provided to allay the fears of the minorities before it granted independence to the country. However, the interpretation of such constitutional guarantees was left to the majority tribes that controlled the government. It is really doubtful whether Great Britain and other European powers in Africa experienced minority problems during their administration. France was busily engaged in cultural assimilation of the Africans and they were even given French citizenship. Thus no tribe was in the position to dominate others. If there were such tribal cultural dominance it was dormant. Great Britain by its indirect rule also restricted the dominance of

18

The colonial government suggested the delay of independence for two years in order to attend to the wishes of the minorities. But the major political parties failed to listen. 
one tribe over another. Each clan which was a sub-division of a tribe had its own leader who directed the institutions of the clan; and there was no fear of tribal or clan subordination. Though Great Britain is at times accused of having favored the dominance of Hausa-Fulani jn Nigeria, and Bakanda in Uganda, the British generally acted as a paternal administrator and saw no purpose in awakening the fears of minorities. It seems that the acute development of minority fears arose towards the end of the colonial exa with the handing of government authority Into the hands of the majority which can come from one tribe and be strongly inclined to ignore the wishes of others. Furthermore, it came up because of the type of poljtical parties which assumed political leadership and the slogans they used. It is important to examine the political parties and the cultural organizations which reveal the political anatomy of Nigeria most clearly. The developinent of political parties in Nigeria has been regional and accordingly reflects local and tribal jealousies. During the Second World War many cultural, literary and professional associations were formed in Lagos. There were also some social clubs and one or two political 19 parties such as the Young Democrats. In August 1944 most of these associations and clubs federated as the National council of Nigeria and the Cameroons. From its composition it seems

19

It was a youth wing of the Nigerian National Democratic Party formed by Herbert Marcauly and based only in Lagos. 
that the N.C.N.C. had few immediate political pretensions, but it did generate nationalistic feelings against the British. The Ibo Union--a cultural organization to promote the advanced education of Ibo--had been formed in 1936. It became a member of the N.C.N.C. By 1948, its leader Dr. Nnamdi Azikiwe became the president of both the N.C.N.C. and the Ibo Union. The N.C.N.C. had many offshoots in Iboland in Eastern Nigeria. Because of the strong ties between the Ibo state Union and the N.C.N.C. the Egbe Omo Oduduwa--a Yoruba cultural association founded in London in 1945--developed more Yoruba-oriented nationalism after it moved its base to Lagos in 1948. In March 1951 Chief Obafemi Awolowo, the Secretary-General. of Egbe Omo Oduduwa set up a political wing, the Action Group, in order to gain control of the Western House that was established under the Macpherson Constitution of 1951. Under this constitution, Lagos, the Federal capital was made a part of Western Nigeria. Dr. Azikiwe vainly opposed the incorporation of Lagos; it cost him his constituency and seat in the Central Legislature. She moved to the East and strengthened the N.C.N.C. He was then elected in Onitsha constituency to the Eastern House where he became the premier of the region in 1953-59. In December 1949 a cultural organization to embrace all northerners was formed in Kano. In 1951 the Northern Peoples' Congress became more openly political in emphasis and it gained control of the Northern Region House of Assembly established by the Macpherson Constitution. The Action Group was the only 
organization formed expressly as a political party, although it stood to oppose Dr. Azikiwe, who personified the threat of Ibo domination. The N.P.C. became a political party to prevent the two southern political parties from dominating the North and shaping the new federal constitution of 1951 to their own advantage. The N.C.N.C. originaily seemed to be the only broadly based organization, but it was much too loosely federated to maintain a common political ideology. It is true that it attacked British colonialism, but by 1951 it was dominated by the Ibo State Union and correspondingly diverted its strength to the East.

In Northern Nigeria, the non-Mosjem and non-Hausa-Fulani in the Middle Belt formed the United Middle Belt Congress in 1955 with the goal of creating the Middle Belt state and thus escaping from Fulani-Hausa domination. Shortiy after its formation the UMBC broke into two faction: the Middle zone League which supported the N.P.C.; and the Middle Belt Peoples' Party which was allied to the N.C.N.C. and the Northern Elements Progressive Union. In 1950 some young northerners broke away from the NPC and they formed a political party, the Northern Elements Progressive Union in 1952. They attacked the northern emirs and their authority which they claimed was conservative. The NEPU was really a political party desiring to oppose and to reform the NPC. Its leader, Aminu Kano, thus appealed to all the dissenters of the North. Based in Kano, the NEPU advocated a united. Nigeria instead of the regional 
ideas of the NPC. While the NEPU was an ally of the N.C.N.C., the UMBC allied itself to the Action Group. The $A G$ and the N.C.N.C. failed to establish themselves in Northern Nigeria apart from becoming allies of splinter parties. In this role the two major parties of the south had to appeal to a wider variety of issues and more divergent elements than they otherwise would have to do.

In the minority area of the Eastern Region, the United National. Independence Party with Dr. Udoudoma as one of its leading members became established. Since some of the leading members of the party belonged to the Ibibio State union--a cultural organization formed in 1928 for educational advancement--there is reason to believe that it served to defend minority interests against Ibo domination. The United National Independence Party sponsored a movement to form a new state that would have embraced all the minority areas of Calabar, Ogoja and Rivers. The COR State-Movement became anti-N.C.N.C.; and the UNIP more or less inevitably became an ally of the Action Group. In 1957 the Action Group-UNIP gained 18 seats from the COR state area while the N.C.N.C. obtained only 17. The COR state movement and the UNIP were regarded as formentors of $i l l$ feeling against the N.C.N.C. and as generators of hatred against the Ibos as well. During the East Regional election campaign of 1962 the COR Advocate press was burnt.

20

Some Nigerian political parties maintained thugs, a group of undesirables, jailbirds, noted criminals, able-bodied unemployed young men and they could do anything during campaign. on electioneering and rallies they went as pressmen and musicians. They acted as secret security officers for certain members of the party. 
Pressure forced the UNIP to disbarld. As a result the COR state movement went underground opposing the sominant bodypolitic of the Eastern Region. When the Rivers and the Southeastern states were created in 1967 by Yakubu Gowan, the Head of the Federal Military Government, the separatist feeIing of the minorities was given expression, as it was minority problems that were one of the causes of the Civil War.

Although the Action Group had passed a resolution in 1955 favoring the creation of the Midwest state, the Yoruba people in the Western Region were not united as a party. There were some N.C.N.C. supporters in the West, but it was not their stronghold and at times what happened to N.C.N.C. supporters in the West reverberated on Action Groupers in the East. Sometimes there were open conflicts between the supporters of these two parties in both regions. In 1958 Alhaji Adgoke Adelabu, one of the strong supporters of the N.C.N.C., had an automobile accident at Shagamu square, Ibadan, as a result of which he later died. His accidental death caused killing, property destruction and fighting between members of the Action Group and the N.C.N.C. In 1962 Dr. Michael Okpara, the leader of the N.C.N.C. came on an election campaign to Uyo North in the East, the constituency of Chief Efiong okon Eyo who was leader of the Action Group. The electioneering produced killing, destruction of property and fighting among the N.C.N.C., the police and the Action Group. Chief Eyo was arrested, later tried and failed, but he won the election in 
jail, while all this was going on, the Action Group in Western Nigeria faced an internal crisis in 1962. The premier of the region and deputy leader of the Action Group was ousted by the leader of the Action Group, Chief Obafemi Awolowo. Chief S.A. Akintola immediately formed a new party to entrench himself in power. Nigeria becane a muiti-party ana multi-tribal society. None of the Nigerian political parties have ever had a strong foothold countrywide; whenever any of them crosses regional lines it has been regarded as a troublemaker and a danger to regional security. When any of these parties make inter-regional alliances, the leaders and supporters of the parties that co-operated with a 'foreign' regional party have been persecuted. The witch-hunting tactics used against such 'foreign' parties obscured the fact that the major party of each region was actually persecuting members of minority tribes of that region who belonged to these parties. The political parties were handicapped in the diffusion of ideas beyond regional lines and tended to become established as the voice of a particular ethnic group in a given governmental region. In 1964 in order to face the general Federal election the NPC and the NNDP joined to form the Nigerian National Alliance while the N.C.N.C., the AG, the UMBC and the NEPU formed the United Progressive Grand Alliance. But the particularistic tendency of the Nigerian political parties from 1951 to 1963 had already affected the unity of the country. The Alliance developed on the eve of the Federal election was 
a marriage of convenience. After the 1964 Federal election the leadership of the country fell to the Nigerian National Alliance, the mainspring of which was the Northern Peoples' Congress that had ruled the country since 1959. The boycott of the 1964 Federal election by the UPGA revealed that Nigerian political parties could nct work in harmony, and that regionalism was triumphant.

The Federal Parliament became controlled by the regionally based dominant political party of the North, the NPC, and the Hausa-Fulani ethnic group which it primarily represented. This situation threatened other regional governments, parties and major ethnic groups. In short, the Federal Parliament became the focal point for inter-regional political differences. The result was turbulence. The Federal parliament controlled by the NPC with the aid of its junior partner the N.C.N.C., declared a state of emergency in the Western Region and dissolved the regional government in 1962. This was the prelude to a series of crises in that region. After six months of emergency administration the Federal government returned power to Akintola's faction which then allied itself with the Northern Peoples' Congress. Events in Western Nigeria were really a test case concerning how the Federal government would conduct itself and if it could maintain the unity of the country. Akintola's

\section{1}

Many members of the NNA in the North were returned unopposed before the election day. The fact is there were some UPGA candidates in such constituencies who were unable to file election papers. The UPGA, therefore, felt that the election was rigged and boycotted it. 
new party, the Nigerian National Democratic Party, ruled Western Nigeria for three years without any election, despite popular demand for one. In October, 1965, the Akintola Government finally conducted an election, but it was at once accused of rigging and other malpractice. At this point, the opposition party, the Action Group countered with a full scale rampage, killing and destroying the property of some of Akintola's supporters. The opposition party even went so far as to set up a rival government. The NPC controlled Federal Government just stood by watching this corrosion of national unity. Such incidents make only too apparent that the distribution of political ideas and the control of the access to power have been great disintegrating forces in Nigeria. The way in which cultural associations were politicized realiy allows national consciousness to be founded on tribalism and the effect is an atrophied national unity. Party politics in Nigeria has produced political restlessness and a tendency to violence, and correspondingly undermines the role of law as a unifying force.

In some African countries, instead of allowing a multinational or regional political parties, a single party has gained a political monopoly. The assumption seems to have been that a unified political party reflects a homogeneous society and that the nation-state can be best given a semblance of unity in the person of a charismatic leader, who is the chief executive and the legislator at ons and the same time. In the Ivory Coast, the Parti Democratique de cote d'Ivoire which started out as a protest movement in 1946 against alien rule like many other 
African parties, later assumed a political nonopoly over the country. In order to wipe out tribalisrn no electoral district was permitted to be congruent with a single ethnic group. With 22 enlarged constituencies the result is that representatives concentrate their appeal on occupztional groups instead of appealing to tribal slogans. Although the supporters of the one party system claim that it is broad-based, there is too much coercion of political dissenters, especially those who come from a particular geographical. region and represent minorities in a clandestine way. Whatever the advantages of a one-party system are from the standpoint of visible unity, there is much curtailment of civil liberties. Moreover, it is tantanount to the supremacy of the elite over the uneducated mass. Whether a one-party system will effectively produce national consciousness in some of the African countries which may adopt such a system is not easy to predict at this time. The state is identified with the party and usually with a single charismatic leader, who, given political realities, may be deposed by a coup. In any case, the attempt to structure national consciousness on a single political party ignores other factors which may in time endanger national unity. It seems that the European powers may to some extent be

22

A.R. Zolberg, 'One-Party Government in the Ivory Coast' Princeton University Press 1964. Twentieth Century Africa by P.J.M. McEwan, (Oxford University Press 1968, London) p. 31 . 
blamed for ushering in the form of party politics which the Africans now have. Throughout the colonial period the vote was restricted to urbanized Africans; only on the verge of independence were most African men and women enfranchised. The Africans who since pre-colonial times had listened with uncritical obedience to their chiefs and elders ware suddenly exposed to parliamentary democracy. The party slogans and election campaigns had tended to reawaken in Africans a kind of traditional war spirit that regards another party as an arch enemy who must be eliminated. Thus in nearly all African countries members of the opposition were suppressed by the parties in power. In Nigeria both in the regions and in the federal government opposition members have faced high-handed treatment by the ruling parties. In Ghana, Dr. Nkrumah and the Convention Peoples Party held Dr. J. B. Danquah, a presidential rival, in jail under the Preventive Detention Acts. He died there. In Sierra Leone, on the eve of independence in 1961 members of the African Peoples Party were jailed to prevent disruption of the independence ceremony. Members of the opposition are frequently regarded as enemies of the nation state; as a result some African countries have resorted to a one-party system. Most of the ruling parties in many African countries remain constantly in power, rather than alternating with the party of opposition. In Ethiopia Enperor Haile Selassie is the state and he does not even allow the formation of any party. In Liberia, President Tubman is a 
lifetime president. It is striking to remark that neither of these countries was ever ruled by any colonial power for any significant period of time; nonetheless, they show the trend of government peculiar to other African countries. In Kenya, the Kenya African National Union has ruled the country since 1961 without any change of hands. From 1955 to 1966 the Nigerian government was dominated by the Northern Peoples' Congress. Ruling parties ordinarily do everything possible to perpetuate themselves, thus causing frustration anong the other political parties which desire to be in the state house. In so far as party politics heighten tribal rivalry and insofar as most of the political parties are regionally based, the tendericy of the ruling party to entrench itself in power obstructs national unity. Perhaps this weakening of national consciousness would not occur if the government were broad based and if the ruling party were not to deny governmental amenities to opposition areas. As a matter of fact, most of the opposition parties would like to criticize the government and yet at the same time they would like to be in the government. The late Prime Minister of Nigeria, Sir Abubakar Tafewa Belewa put it in this way:

In Nigeria, no party can agree to be in opposition for long. A political opposition in the Western accepted sense is a luxury that we cannot afford.... The trouble is that the Nigerian member of Parliament wants to criticize the government and to be in it at the same time. Democracy, democracy--what is it? There is American democracy, British democracy--why not a Nigerian democracy? I wish we could find that? 3

23

West Africa, No. 2539 (January 29, 1966) pp. 113-14. 
Thus it can be seen that it is not really party politics as such that should be held accountable for national disunity, but it is actually how the Africans understand party politics and apply it. It is true that party politics came indirectly with the European powers but for years the colonial powers looked with jaundiced eye on the formation of political parties. Most of the African political parties developed out of protest movements against alien rule. In Kenya the protest movement $24 \mathrm{a}$ manifested itself in the Mau Mau uprising led by the Kikuyu people. The result was to deprive the Kikuyu of open political organizations as long as emergency regulations were in effect. In Madagascar, the Madagascar National Movement (MORM) was proscribed in 1948 because of its agitation against the ties between the island and France. The Rassemblement Democratique Africain (RDA) of the Ivory coast faced colonial harassment since the party wanted coloniai government to respect the citizenship rights of Africans. In 1955 the Union of Cameroon Peoples advocated the reunification and independence of the

\section{4}

In 1940 the Kenya colonial government suppressed the formation of Kikuyu Central Association. In Nigeria in April 1950 the Nigeria colonial government disbanded the zikist Movement although in May it came out with a new name; the Freedom Movement.

$24 a$

The Kikuyu people revolted against the European settlers because the Kikuyu land was taken away, and as such the Kikuyu were deprived of coffee farming. The revolt lasted from 1950-56.

\section{5}

The emergency was declared in October 1952 and lasted till October 1960 . 
divided Cameroons; the party was asked to disband by the French colonial government. The two major colonial powers in Africa at first did not look favorably on the formation of political parties; and only during the interim period before independence were they allowed to function as political parties per se. But in the formation the political parties became regionalized and tribalistic; and all too often in the application of party politics oppression and violation of civil liberties occur. Consequently disillusionment and disenchantment engulf the elements which are not a part of the ruling clique. The manifest frustration on the part of the minor parties endangers national unity, and the ruling party's attempt to uproot these splinter parties deepens the polarization.

Let us turn from the political history, regionalized as it is, to an explanation of the geographic distribution of population as a potential threat to Nigerian unity. During the 1962-63 cersus the population of Nigeria was 55.7 million, distributed as follows: Northern Nigeria, 29.8 million;

Eastern Nigeria, 12.4 million; Western Nigeria, 10.3 million; Midwestern Nigeria, 2.5 million and the Federal territory of Lagos, 675,000. The area of Nigeria comprises 356,699 square miles divided as follows: Northern Nigeria 281,182 square miles; Eastern Nigeria, 29,484 square miles; Western Nigeria including the Midwest, 45,376 square miles, and the Federal territory of Lagos, 27 square miles. Nigeria has an average density of 164 persons per square mile. The North has 106 
persons to the square mile; while the West including the Midwest has 282 persons per square mile. In the East density reaches 419 persons to the square mile, while the concentrated urban population of Lagos hits 25,000 persons per square mile. It is clear that population density is much greater in southern Nigeria--Lagos, West, Midwest and East--than in the North.

In a few areas especially in the South the population density of 400 to 500 per square mile has reached the limit of what the land can support under the present agricultural methods and here population pressures have resulted in...migration of the inhabitants. On the other hand, there are wide areas, as in the Northern Region... which are thinly populated or virtually uninhabited.26a

This pressure on the land is further complicated by differentiating land laws. In some parts of Southern Nigeria customary law recognizes the right of permanent alienation; in the North all land is held by the government as a trust for the native population. Non-Northerners are strangers who must obtain the right of occupancy. The possibility of using the North as an outlet for the heavy over-population in the South, and especially the East, was in a way checkmated by permitting the Southerners to live only in Sabon-Gari without full absorption into the body politic of the North. This containment of non-Northerners on the periphery of Northern towns frustrated the settlers who found themselves treated as infidels. These measures in practice undermined Nigerian citizenship.

\section{$26 a$}

The Economic Development of Nigeria. Report for the International Bank for Reconstruction and Development (The John Hopkins Press, Baltimore, 1955) pp. 10-11. 
The concentration of population in the South to a certain extent may be attributed to the British administration. For when the British administrators first arrived they settled along the coast and developed the coastal towns such as Lagos, Port Harcourt and Calabar. Roads and railways radiated from the coastal towns inland. Thus regional inequities of population density emanated from European coastal development. until the problem of inter-regional settlement is given badily needed legislative attention, population pressures will continue to feed regional animosities.

The population census of Nigeria has been given much political significance, for representation in the Federal House of Representatives was based on geographic distribution of population. The Federal House of Representatives had 312 members. Out of this number 167 seats were allocated to the 26 North. The East had 70 seats while 57 went to the West. The Midwest was allocated 14 seats and the Federal capitol of Lagos had 4 . While other areas in Nigeria practiced adilt sufferage, the North excluded women from voting and holding office. The population census of 1962-63 itself produced a series of controversies and inter-regional conflicts. The Federal Government which controlled the population count was sued by the East regional government. The suit failed because

\section{6}

In 1945 the Northern leaders had demanded representation equal to the combined seats of the East and West. Between 1945 and 1953 the House had 148 members. Between 1954 and 1956 it had 184; and between 1957 and 1966 it had 312 . 
the court claimed that it had no jurisdiction over census issues. This helped increase the loss of faith in the nation by some Eastern leaders. On the basis of the population census majority government for the whole of Nigeria was decided and the decision was in favor of the North. Northern control of the Federal Government was difficult for some Southerners to accept because of alleged inflated figures from the North, and above all, because of the lack of fairness of elections in the region. Although the Southern politicians accused the Northerners of the 1962-3 census inaccuracies, it must be emphasized that all the regional governments of Nigeria manipulated the census figures of their regions to gain more seats in the Federal Legislature, and all the regions controlled their elections in order to maintain the status quo.

It is clear that the distribution of population in Nigeria has been much politicised and it is a source of conflict, more especially since the region with the most numerous inhabitants has obtained a predominating position of power despite the fact that the rest of the country is more highly developed in terms of assimilation of western ideas. In other words, the problem is the inability of the relatively few intellectuals concentrated in the South to control the government of the country. In some other African countries, such as Kenya, the political power and numerical strength of the majority tribe, the Kikuyu, are also reflected in the composition of the nation's elite. The Hausa-Fulani control of the government in 
Nigeria reflects the concept of majority rule but does not entirely do away with the question of whether the un-Westernized mass should sacrifice its sovereign will to an intellectual oligarchy. From this standpoint the unity of Nigeria is hindered not by the geographical distribution of population as such, but rather because the majority exercised political power without corresponding Westernization.

To some extent Northern control of the Federal Government because of its population strength can be blamed on policies of the English colonial administration. In 1945 Sir Arthur Richards formulated the Richards Constitution which for the first time brought the South and the North together in one central legislature. In the draft constitution thirty seats were proposed for the North while twenty-two seats each were allocated for the West and the East. Although the draft Richards Constitution took into account the numerical strength of the North, the Northerners demanded a representation equal to that of both the East and the West. The issue of representation in the Central Legislature became a major disagree27 ment and almost brought work of the General Conference to a standstill. The Governor-General bypassed the stalemated General Conference; he submitted the problem created by the Northern demands to the existing Legislative Council of Nigeria,

\section{7}

The members were nominated by the governor and the administrators of different provinces. In addition, there were members of the Legislative council. 
the membership of which had an official British majority. The Legislative Council decided in favor of the Northern demand and thus sold out the South to the North. The Richards Constitution and the Legislative Council of Nigeria were, it appears on hindsight, misdirected in allocating more seats to any region of Nigeria.

Between 1903 and 1943 the population of Nigeria was counted only in the major towns; and in 1953 when the count was spread to the countryside the people refused to cooperate 29

and returned low figures. While in 1963 when the post-independence population census was made there was much exaggeration because of the political campaign and the advantages a high return might have. Thus in 1945 the determination of representation according to the population census could not accurately be accomplished. The allocation of a majority of the seats in the Central Legislature to the North allowed the North to develop as a strong regional bloc in opposition to the Southern forces. It also created a precedent that the North would scarcely relinquish and which the South felt forced to offset.

\section{8}

In 1929 a rumor that a census was to be taken in the East produced the 'Aba Riot'.

29

The people associated head count with taxation and the greater the number of people returned in a home the more tax money to be collected from the head of the household. Also, there was a superstitious belief that people who are counted may die. Furthermore, there was no program to educate the people. 
Regional differences in the acquisition of Western ideas act as a hindrance to any general cultural assimilation and practice of democratic principles in Nigeria. In 1926, barely twenty-six years after Great Britain had assumed direct administration of Nigeria, there were 138,249 pupils in the primary schools and 518 in the secondary schools of Southern Nigeria; while in the North there were only 5,210 in the primaxy schools. No secondary schools were established in the region. By 1947, two years after the introduction of the Richards Constitution, there were 538,391 primary school pupils and 9,567 pupils in the secondary schools of Southern Nigeria, compared with 70,962 pupils in the primary schools and 251 in secondary 30

schools in the North. The 1952 population census revealed that there were 834,266 literates in roman script in the East; 769,933 in the West including Lagos, compared with only 250,707 in the North. The North also had 656,259 literates in Arabic 31

script. In 1963, three years after Nigeria had gained its independence, Southern Nigeria registered 2,485,676 pupils in primary schools and 231,161 in secondary and post-primary institutions. The North, on the other hand, had 410,706 pupils

30

Annual Report, Colony of Southern Nigeria, 1906, p. 199. Annual Report, Northern Nigeria, 1900-1911. p. 47-8.

African Education, (Oxford: Nuffield Foundation, 1954)

31

Population Census of the Western Region of Nigeria, 1952

(Lagos: Government Statistician, 1953-1954). Population Census of the Northern Region of Nigeria, 1952

(Lagos: Government Statisticiari, 1952-1953). Population Census of the Eastern Region of Nigeria, 1953 Bulletin No. I (Lagos: Government Statistician, 1954). 
in primary schools and 20,312 in secondary and post-primary schools, yet the North contains about 54 percent of the population of the country. Only about 25 percent of the literate population resides in the North. This variation in the distribution of educated population is an important fact to be considered, not simply as population count that has favored Northern control of the Federal government. From this high rate of literate population in the South it can be inferred that there has been a change to a money economy, more accumulation of western technology and a high urban-rural ratio, and perhaps, the rise of a new midale class. The per capita income in the various regions in Nigeria confirms this impression: $\$ 95.20$ in the West; $\$ 47.60$ in the North, and $\$ 58.80$ in the Eastern region. These factors are likely to produce detribalization. The continuation of unweakened tribal organization in certain areas of the country in political association with areas of more rapid modernization clearly affects Nigerian unity.

Rerhaps in this context the British administration can be criticized. In colonial times about 98 percent of the schools in Nigeria were established by missionaries, and about 97 percent of all educated persons in the country went through mission schools. But in January, 1900, when Lord Lugard became the High Commissioner of Northern Nigeria he insisted on maintaining all the pledges of the Royal Niger Company. Accordingly, Christian missionaries were not allowed to proselytize in the North. In 1902 the High Commissioner issued the following 
report:

I am myself of the opinion that it is unwise and unjust to force missions upon the Mohamnedan population, for it must be remembered that without the moral support of the Government these missions would not be tolerated. And if they are established by order of the Government the people have some cause to disbelieve the emphatic pledges I have given them that their religion shall in no way be interfered with. 32

Interestingly enough, the Colonial office in 1917 restated the policy that anything that threatened the Islamic religion in the North endangered the authority of the emirs and thus undermined the system of Indirect Rule. By barring Christian missionaries from the North unless they were invited by the Mohammedan emirs, the North was procluded from coming in contact with European culture in the form of western education. Yet these Northerners later had to share and to interpret the complex and alien Richards Constitution of 1945 . Such differences in the reception of western ideas, largely the effect of missionary enterprise, has contributed to regionalism in Nigeria. The failure of Great Britain to encourage religious conversions in Northern Nigeria in line with the rest of the country can perhaps be regarded as a hindrance to national unity caused by the European powers. The British colonial policy did not interfere with native religion unless it involved cannibalism and human sacrifice. The Islamic religion prevalent in Northern Nigeria did not affect law and order, the most essential concern of the European powers. In fact, traditional religion and culture of the North University Press, Landon, 1937 p. 286. 
were steadying influences favorable to the European presence. The North may seem detached from the South in the assimilation of western ideas but it was not exempted from the economic and political objectives of colonial rule.

There are many differences in development and urbanization which deepen the forces of regionalism. Northern Nigeria has been fortunate to possess such extractive industries as the tin-columbite mines of Jos and the iron of Lokoja. Kano has been the hub of commercial activities and light industries of the North. In the South there are the oil wells of the Midwest and the East, and there is also the coal of Enugu, although it is of poor quality. In the generation and distribution of electricity the South has such centers as Lagos, Abeokuta, Ibadan, Oshogbo, Benin, Sapele, Warri, Port Harcourt, Aba, Calabar, Onitsha, Oji River, Enugu and Abakaliki. On the other hand, the giant North has eight locations at Kaduna, Jos, Yola, Maiduguri, Zaria, Kano, Katsina and Sokoto. The economic development of the North is not comparable to its size; nor does it match the progress in the southern areas. Thus the growth of towns and urbanization which follows an economic development has been limited. Economic problems become nearly insoluble because of the conflict of interests imbedded in regional politics. The Federal Economic Council vas supposed to handle such problems, but in 1963 a decision whether to locate an iron and steel industry either at Lokoja, an iron mine in the North, or at Onitsha, a populous commercial center in the East, could not be reached because of the political 
publicity given the issue by the premiers of the-East and North.

Some would gladly blame the colonial powers for the various differences in development characteristically found in most of the African countries. The European powers developed those areas of their colonies where either agricultural products or mineral resources could be obtajned. After all, the supply of raw materials was one of the chief reasons for acquiring a colony. The European powers therefore tended to develop those sections which would provide maximum resources or support a self-sustained economy. But African leaders since independence was gained have concentrated development in those areas which had already been developed by the colonial powers, and they amplify existing disparities. In some African countries development becomes part of the spoils system, rewarding those areas which voted for a government party. For example, in Nigeria many of the minority areas which did not support the ruling regional parties were denied economic opportunities. Disenchantment has resulted from the failure of the ruling parties to live up to their pro-independence pledges of 'Life 33

Abundance' promised to the masses. Life Abundance failed to spread out to the lower ranks of society because of the way governmental favors were manipulated by the ruling party. It is inevitable that political consideration should enter into decisions concerning economic development but its role should

\section{3} Western Nigeria. 
be restricted. Too often some of the ruling parties employ the location of industry and amenities as a means of winning votes from the electorate.

At this point we shall turn our attention to the problem of moral values in differentiating attitudes of Nigerians towards fellow members and their country as the greatest force working against integration. In short, in nearly all the African countries there has been moral erosion and the development of differing attitudes which retard the growth of national unity. Of the twenty-eight black African countries which have gained independence about twenty-four have experienced either a successful coup or an abortive one. In a typical military takeover, the army declares it will rid the country of tyranny, bribery, corruption and nepotism, yet it does not easily do so. Where civilian governments are in operation, some members of parliament try to use their influence on the government for their ow personal advantage, justifying that they had spent a huge sum of money during electioneering. Applicants for government jobs often have to buy their positions from the ministry controlled by a politician. Many government and corporation employees feel that if a person wants speedy and efficient service such a person should make some sacrifices. The President, the Prime Minister and the Ministers' tribesmen are always favored in job opportunities; and at times a job vacancy may not be announced until a tribal member to fill such a post is found. As a result tribal rivalry is fed on the least powerful tribes, and the unity of all the tribal groups 
stands in doubt.

In Nigeria, as well as in other African countries, there is little or no sense of common nationality among the citizens. Nigerians still regard themselves as aliens in their own country and strangers among their own people. A Nigerian finds it hard to think of his country as a greater unit than his native region, and his country to him is not as important as his tribe. Normally either the tribe or the clan is the object of an individual's greatest loyalty.

To some extent these problems of changing attitudes and moral corrosion may be blamed on the European powers which colonized Africa. The traditional mores of the Africans were broken down by the introduction of the Western culture, especially by ideas of equality and a questioning of traditional deference to age. The traditional African society in which a person's actions and deeds were regulated by public approval and ancestral spirits has been devalued by European cultural attitudes. An African once knew that when he broke his society's custom he faced either a taboo or a series of rituals to appease the gods. But now urban centers--outgrowths of European colonialism--serve as a haven and a hideout for such offenders against traditional customs. An African who formerly felt himself to be at the mercy of his ancestral spirits and the earth deity, who lived in constant fear of the supernatural often now has become a convert to European Christian religion which emphasizes the accountability of the 
individual conscience to God. Thus the individual priesthood or the individual direct cormunication with his Christian god disrupts the community ethics. An African now has to bear his moral burden arising from either his actions or inaction himself. He is liberated from the belief that his moral actions would either be a shame, or a source of glory to his community. An African's Iife was once submerged in and sustained by the group, but now indivioual life increasingly overshadows communal life. Although many an African was intimidated by the fear of heli and heaven to accept the European religion, it is really the African's desire for the attainment of modernity in his life that is producing moral change. An African accepted Christianity because he either wanted to free himself from a traditional authority or he wanted to acquire prestige and to gain material benefits. But African Christians easily and speedily return to their fetish practices if they feel that misfortune has befalien them. It is true that the different Christian denominations have produced differing attitudes among the Africans since they could not marry and associate with non-members of the sects. But in pre-colonial times Africans did not marry outside their tribe or clan and members of some African cults did not associate with non-members. Thus the variation in attitudes of Africans towards one another is partly caused by European factors and partly sharpened by the African conditions. A member of the African elite simply because he had got a financial opportunity 
to acquire western education becomes snobbish toward r.onwesternized Africans. When there is a large concentration of western educated men in one tribe the disintegrative effect on national unity is untold. Any such claim of superiority is likely to be resisted by other tribes who compose the nation state. Traditional African values iimited social contacts to 34 people of unquestionable character and the unacceptable behavior of a given person could be transferred to his extended family and community. If the unacceptable code of conduct is generaiized to take in either a clan or a tribe the unity of the country is thus affected. It seems that this African attitude has a great disruptive influence on national unity since Africans would cooperate with a people whom they like, and the building of national unity needs the cooperation of all sections of the nation.

National unity has meant different things to the various groups that advocate it. The National Council of Nigeria Citizens championed one Nigeria insofar as its nembers would identify their tribal group interest with Nigerian nationalism, and as far as most of its trading members would move unmolested in any part of the country. To the Action Group of Nigeria, unity was embodied by the creation of numerous federated states. fnd to the Northern Peoples' Congress the unity of Nigeria was subject to the idea of Northern hegemony. The westernized

A thief, an adulterer, a trader who cheats, a witch doctor, a person who has money by gambling, a person who reveals a secret and young men who fight constantly with their parents or any other elderly person were not associated with. 
elders have not decided on what elements of the colonial life they want either to adopt or adapt. In Northern Nigeria the people demanded parliamentary representation but the Northern women were not emancipated as were their counterparts in the south. In Southern Nigeria the elite talk of majority rule but they opposed Northern dominance. Some of the Nigerian. political leaders preached the politics of power and the 35

protection of their domain instead of the politics of national unity. Divisiveness has constantiy plagued Nigerian national consciousness.

British colonial aâministrative practice was responsible to some degree for the regionalism that plagues Nigeria. The first British administration was the consulate established in 1849 for the Bights of Benin and Biafxa, with headquarters on the Spanish island of Fernando Po. Later, John Beecroft moved the headquarters to Calabar which was located within the Oil 36

Rivers Protectorate--an area of land east of the Niger covering

35

In $1963 \mathrm{Dr}$. Nnamdi Azikiwe, the President of the country, toured the North and remarked on the piight of the Northerners. He was criticized by the Northerners for making such remarks. Dr. Michael okpara, the Premier of Eastern Nigeria, announced a tour of the West but the Western House of Chiefs passed a resolution banning okpara from the region, but he went into the West.

36

This was an area where the livelihood of the people depended on the production of regetable cil--palm oil--and the oil has been the main export of the area. The trade in palm oil replaced the trade in slaves after its abolition in 1833. 
the Delta and extending to calabar. The 011 Rivers Protector37

ate, established in 1885, at first had a separate consular administration but in 1893 the Oil Rivers area was given a new name, the Niger Coast Protectorate, and extended to cover an area west of the Niger. It was also administered by a consular general. West of the Niger Coast Protectorate was Lagos, which in 1853 was created as a separate consular area in an effort to control the high incidence of slave trading. Within the Niger Coast Protectorate there was no uniform progress in aäministrative organization. The clan system worked better in Warri and parts of Calabar than among the Ibo of Owerri and Onitsha where the people were not used to being grouped within a large administrative unit. The Niger Coast Protectorate, which extended on both sides of the river Niger and was established particularly to look after the interest of the European traders, became the Southern Protectorate in 1900 under the rule of a governor. The Southern Protectorate with a population of about 8.5 million in 1921 out of the total of $18,765,000$ for the whole country, had its own separate government departments. In 1939 the Southern Protectorate was split into the East and the West Provinces with a population of 4.8 million and 3 million respectively. Each was separately administered, and the separate identity of the two regions thus emerged.

37

The Berlin Act of 1885 declared the Niger with all its tributaries an international waterway ano many British and other European traders converged in the area. 
However, the Britisi administrator of each yrouk of provinces was subject to the chief administrator for the entire country. Lagos, which had been declared a separate consular area in 1853 , became a colony in December 1 1 61 . The Yoruba ruling chief, Docemo, ceded full sovereignty to the British government. Lagos was colonized under the British J.aw and was administerea directly by the British officials. While in the Southern provinces the natives were British protected persons, the residents of Lagos were regarded as British subjects. In 1866 the administration of Lagos was directed from Sierra Leone; then in 1874 the administration of Lagos was merged with the colony of the Gold Coast, now Ghana. Between 1881 and 1885, the inhabitants of Lagos protested against the loss of their separate administration. As a result the administration cf Lagos was separated from the Gold Coast in 1886. In 1906, the colony of Lagos, despite a very different system of government, was merged with the Southern Protectorate, the seat of government for which was at Calabar. In spite of the amalgamation, Lagos was ruled by a separate administrator while the Southern Protectorate too had its own commissioner. But the two administrative areas were placed under a governor, Sir Walter Egerton. The colony of Lagos continued its separate administration as a territorial area until the constitution of 1951 which made it a part of the Western Region. In 1954, Lagos was separated from the West and declared the Federal Capital. The separate status of Lagos reached its climax in 
May 1967 when Lagos became one of the twelve states created by General Gowon.

If Lagos and the Southern Protectorate revealed differences in administration, the Norch presents yet another contrast to confirm British administrative regionalism in Nigeria. The government of the Northern Provinces fron 1886 to 1899 was the legatee of the Royal Niger Company. With the revocation of the company's charter in 1900, a British High Commissioner assumed the control. of the North. Between 1900 and 1906 the High Commissioner, Lord Lugard, conducted a series of wars to pacify the North. Even though Northern Nigeria was occupied by military conquest, the High Commissioner introduced Indirect Rule in the region. From 1900 to 1914 Northern Nigeria enjoyed its independent administration under the commissioner's supervision.

In 1914 the Colony of Lagos and the Southern Protectorate, and the Northern Protectorate, were amalgamated under a single governor-general, Lord Lugard, previously the High Commissioner of the North. Perhaps because of the First World War and the resultant shortage in staff and finance, perhaps to coordinate the economy of the two territories, a unification program was undertaken. Yet in spite of the amalgamation each protectorate had its own lieutenant governor. The amalgamiation was not very effective for by 1923 the medical and education departments were still not unified. It was only in 1933 that the police departments of the two areas were unified. In 1922 a Legis- 
lative Council was established. The President of the Kano Chamber of commerce was one of its members. But strikingly enough, the Legislative council only made legislation for the South; and legislation for the North remained in the hands of the lieutenant governor. In 1929, Nigeria was divided into four administrative units: the colony, the western, the Eastern and the Northern Provinces, each administered by a Commissioner. In 1945 the Richards consitution strengthened the regional grouping by giving each unit fairly broad powers. However, the Richards Constitution brought all the regional members into a Central Legislature which approved all bills and financial legislation for the whole country.

Although regionalism may have been in an embryonic stage, the Macpherson Constitution of 1951 and its revision of 1954 gave the regions greater autonomy. The British government based the political unity of the country on the three component autonomous regions. It is this three-regional structure of government which has proved so difficult in practice. Perhaps the unity of Nigeria would have been better developed if more states had been created. Chief Awolowo, the ex-Premier of Western Nigeria could not justify the arbitrary grouping of the federal government, instead, he advocated the grouping of Nigeria into various autonomous states on an ethnic basis.

38

Awo, The Autobjography of Chief Obafemi Awolowo. (Cambridge University Press, 1960) pp. 174-76. 
For more than fifteer years some Nigerians have blamed the colonial administration for the constitution which failed to provide more states as the Achilles' heel of national unity. In May 1967 General Gowon decreed the creation of twelve states in Nigeria, but by doing so he helped to precipitate the civil War since Eastern Nigeria (Biafra) was opposed to the dismembering of its region.

British colonial policy and administration varied as governments and administrators changed hands in London. Except for brief interludes under Gladstone who limited imperialistic designs, the period from 1885 to 1905 saw Lords Salisbury and Rosebery as Prime Ministers, both strong advocates of imperialistic expansion. Thus private trading companies were chartered to acquire and rule some foreign territories. The Royal Niger Company and the British Consul ruled various territories in Nigeria from 1885 to 1900 . It was not easy for the interest of the trading firms to be entirely eliminated when the British government took over direct responsibility for the various territories. Lord Lugard, an agent of the Royal Niger Company, a military commander of the company's armed forces--the Royal West African Frontier Force-became the High Commissioner of Northern Nigeria 1900-1906 which had been the main domain of the company. Between 1906 and 1914, the Liberals under Balfour and Asquith took over British government and reorganization of Nigeria resuited. In 1906 Lagos was unified with the Southern Protectorate and in 
1914 the Northern Protectorate and the South were amalgamated. It seems that the amalgamation on the part of Great Britain was effected because the idea of free trade was dying and British trade was facing increased difficulties in European markets. Britain had to adjust its colonial conditions to make the situation favorable to her town-bred middle class who depended on trade and industries. Lord Lugard becane the governorgeneral of Nigeria 1912-1918, to implement the unification program. It seems that Lord Iugard's objective was to foster law and order, which in turn would encourage profitable trade. Lord Lugard did not use the system in effect in the southern protectorate--direct British administration in the colony of Lagos, district and county councils on an English model in most places in the West and in the East. He admired the Northern system of Indirect Rule and introduced it to the South. By so doing he ignored the Westernized Atricans in the South. Perhaps he was disdainful of them because of their demands, and perhaps there were not enough Westernized Africans to assume ruling responsibility of the whole cciuntry. In any case, Lord Lugard appealed to the traditional rulers who were in the majority and who could foster stability to promote trade, justice and peace for Britain. The future national unity of Nigeria was affected even at that early time because of the differences between the forces of change manifested in the

39

The inhabitants of Lagos demanded a separate administration from Sierra Leone and the Gold coast. 
Westernized Africans in the South and the forces of stability embodied in the Islamic leaders of the North.

From 1900 to 1914 Nigeria was not administered as one country, largely due to the continuing effect of its piecemeal acquisition. Between 1914 and 1951 the country was ruled under a unitary form of government symbolized by the GovernorGeneral, one budget, one legislature and one civil service. But between 1951 and 1959 the strong central government was dropped in favor of the federal structure which the country still. maintains. Thus Nigeria has undergone various changes of government since 1900 which have considerable bearing on present problems of unity and disunity. At the same time, the regionalism in Nigeria must be examined in the totality of the Nigerian society. In 1953 a riot broke out in Kano between some Northerners and Southerners simply because some Northern nembers of Parliament were booed at Lagos; and an opportunity for revenge occurred when a Southern politician announced a tour of the North. In 1965 the academic community of the University of Lagos witnessed a bitter quarrel among the university professors because an Ibo vice-chancellor, professor Eni Njoku, was replaced by Professor $S$. O. Biobaku, a Yoruba. Thus in all segments of Nigerian society there are regional and tribal attitudes which more than anything else weaken national unity. It is really the lack of good human relations or good neighborliness which paralyzed the unity of the country. This is the role of other African states too. 
In Kenya, Uganda, and Chad various ethnic groups are very sensitive towards one another.

Some writers have blamed the European powers for having created European nation states in Africa, instead of building tribal states as a more viable basis for independent existence. But a study of the African tribes would reveal that some of the tribes are not homogeneous except in name. Within the Fulani tribe for example there are such sub-units as the cow and the Town Fulani. In the Ibo tribe there are such subdivisions as Nnwa, Abiriba, Onitsha and Owerxi peoples. The Yoruba tribe has sub-groups such as the Egbas and the Ijebus. Sometimes there may be quarrels and fighting between differing dialect groups of the same tribe.

Aside from such lack of homogeneity within a tribe, a tribal state would not have served as the real objective of having a colony. The imperialistic powers were not to all intents and purposes to build a political state, but simply to organize an economic area. The larger the size of a common market, the better it was. If the idea of building a political state ever manifested itself in the British colonial plan in Africa, the British regarded it as a gradual approach. The French regarded their colonies as extensions of metropolitan France with the goal of assimilating the natives. The Belgians took their colonies as possessions that could only enjoy the benevolence of the Belgian king. The spaniards, the Germans and the Portuguese looked upon their African colonies as 
natural resources which were to be exploited. It must therefore be emphasized that it was for commercial interest that the territories were first occupied, and most of the countries were acquired either by private traders, missionaries and chartered companies. The metropolitan government involvement followed rather later and sometimes quite reluctantiy.

To some extent the two major colonial powers attempted to unify some of their territories economically. French West Africa, which comprised Senegal, the Ivory Coast, Guinea, Dahomey Soudan, Niger, Mauretania, and Jpper Volta, was administered as a federation after 1904. The governor-general who was responsible to the Minister of colonies, had his headquarters in Dakar in Senegal. Until 1945 the French monetary system circulated throughout the Federation, but in December 1945 the Federation issued its own currency--the French Colony of Africa franc. This was a result of the deterioration of the French franc during the second World War and it was essential to save the economy of the colony. The Federation had its own central bank in Senegal which issued paper currency for the area. With independence of each of the countries, the common currency has been withdrawn.

Great Britain, on the other hand, failed to federalize either its West or East African territories under a governorgeneral. British West Africa, which consisted of the Gambia, Sierra Leone, the Gold Coast and Nigeria, used a common paper currency--the West African Currency Note. To improve production 
of agricultural raw material: a West African Institute for Oil. Palm Research was established at Benin in Nigeria for ali the colonies. After independence of each of the countries the former British West Africa decided to maintain the Research Center but at the same time they withdrew the circulation of the common currency. At any rate, an exanination of the situation in the former colonies reveals that in spite of all the diversities there are certain socio-economic forces favoring unity.

In Nigeria, the various regions of the country are well linked by means of communication. The Niger-Benue Rivers with their tributaries provide important water transportation routes to the various sections of the country, though rapids and waterfalls on the Niger-Benue obstruct free movement on some reaches of these rivers. The Niger-Benue link the North to the South. The military headquarters of the Royal Niger Company was established at Lokoja, the confluence of the NigerBenue, while the trading center of the company was located southward on the Niger at Asaba. Burutu and Warri on the Niger Delta becarne headquarters of such trading firms as the United African Company and John Holt and Company. Baro on the Niger in Northern Nigeria was developed as a port to link the various trading areas of the South with the North.

As trade proceeded inland railway lines were constructed to link the inland markets. The railway system radiated from the coastal towns. In 1896 the construction of the first rail- 
way line from Lagos to Oshogbo, a cocoa area in Y்orubaland, was begun. This Western railway system joins Minna, a gold mining town with Baro, a port center in the North. By 1911 this railway system reached Kano, the Northern market for peanuts, hides and skins, and caravan trade. East of the Niger from the port town of Port fiarcourt on the Niger delta, a railway line was laid in 1912 to reach the coal mining town of vai. In 1927 the Eastern line was extended to Jos, the tin-columbite mining center in the North. After the First World war the road system as developed was an extension of the railway lines and in most cases the roads intersect with the railway lines.

Apart from transporting the bulky products from one part of the country to another, these lines of comrunication have helped Nigerians and the administrative officials to move from one part of the country to the other. This movement of people is creating a social mix new to Nigeria. The communication system encourages a iarge amount of internal trade within the country. Thus livestock, grains and cowpeas from the North and the Middle Belt, kola nuts from the West, garri and yams from the Middle Belt and the East circulate freely in all parts of the federation. Tribal differences notwithstanding all the various regions of Nigeria are complementary to one another in domestic marketing. With good means of communication which each African country should list in its priorities the social mobility would produce a mutual understanding to speed up national consciousness. 
Many new towns such as Jos, Kaduna, Enugu, Baro and Port Harcourt were opened in Nigeria and elsewhere in Africa by the European powers, mostly as markets or administrative centers. With the introduction of a money econony and the corresponding preference for cash income, many Africans migrated to the towns. This movement to urban centers has promoted detribalization as well as urbanization. A sense of national identity is cultivated in the towns since members of many tribal groups mingle there. If many new towns were established, the pace of detribalization would quicken a resultant growth of national consciousness. Of course, the influx of people into the towns might also bring a high rate of unemploynent and crime, but these incidents should be regarded as a challenge. Instead of concentrating industries and development projects in the few congested old towns some government projects could be used in opening up new towns. All sections of the community would then benefit from governmental projects insteac of only the presently favored areas.

Through the efforts of the early missionaries, the European powers had founded schools along the coastal and riverine areas. In French West Africa the Catholic missionaries spearheaded education until 1903 when the church and the state were separated in France. In Nigeria, the Catholic missionaries founded the first school at Lagos in 1844, while the Church Missionary Society founded a school at Calabar in the East in 1847. At first the goal of European education was 
to enable the Africans to read and write and thus equip them 40 to serve as interpreters, teachers and clerks. European education created certain common bonds among many Africans and it served to engender national awareness. Some educated Africans may quarrel over appointments such as have been made at Lagos University, but education has allowed them to cross regional lines and as a result these Africans are better able to understand other tribal groups. These educated Africans have formed trade unions which are countrywide. For an instance, the Nigerian Union of Teachers caters to the interest of all teachers in the country. With great advancement taking place in education and with proper reorganization of education towards national interests--instead of a tribal language, French and English and other tribal languages should be taught and African history should be developed--a new Nigerian profile can be given expression. Maybe the new Nigerians will even be able to modify the cake of custom that at times forces them to marry within their own tribe. In an attempt to weaken social rigidity, marriage outside the tribe should be encouraged, perhaps by means of preferential bride-price. The European powers have created directly and indirectly some bonds

40

Originally these types of work were done by freed slaves from Brazil and Sierra. Leone.

41

Bride-price cannot be eliminated at the present rate of literacy in Africa. Because of the high bride-price in some areas some educated Africans prefer foreign wives. 
of union--the colonial rule, constitution making and independence of course, the slave trade which they accentuated, legitimate trade and education which they activated, and the resulting encouragement of social mobility. Political unity is really the responsibility of the Africans for the European powers were not in Africa to buila a natior-state which would compete with the metropolitan country, but sather wanted colonies to complement the mother country and serve its needs. 
CHAPTER IV

CONCLUSION

The European powers during their scramble for Africa removed the old political formations based on ethnic groupings and substituted almost everywhere new territorial groupings. The formation of territorial states satisfied the need of European interest groups for large markets and alsc corresponded with European conceptions of government. Sectionalism and particularism existed in the new territorial states but they did not affect European econoric interests. The change to money economy, and above all, the European's military superiority, kept political separateness at bay. But the Second World War marked a new stage in the African's contact with the Europeans and called in question the earliex European superiority. The self-determination clause contained in President Woodrow Wilson's Fourteen Points was echoed and re-echoed by a small vanguard of African elite who were not content to remain in a static position vis-a-vis the European. The wave of demands for independence caught the European powers relatively unprepared. Between 1945 and 1946 France by its Monnet Plan, Great Britain by its Colonial Development Fund started more economic development for their territorial 
market areas. A political transformation took shape in Nigeria in 1945 when the Richards Constitution was drawn up and the North and the South for the first time were brought into one Central Legislature. France by its constitution of 1946 allowed elected African natives from the colonies to sit in the Constituent Assembly. By 1956 the loi cadre launched French African colonies on the way to internal autonomy within the French Union. To all intents and purposes it was the pressure of events that forced the major European powers to prepare their colonies for political independence. It was really too short a period of time for the African countries to acquire all the mechanics of Western democracy or even to produce a national consciousness. Most of the colonies gained independence between 1957 and 1963 when they had been ruled by foreign powers for over fifty years.

It is true that the period since decolonization has also been too short for the African countries to achieve nationai unity, but all politico-socio-economic forces should be employed by the African leaders with the goal of increasing national unity. A change of attitude is needed, especially in light of the disparities existing in each of the countries. A reorganization of the political parties on a countrywide basis and the government being broad-based should be envisaged. In Nigeria there were 312 members in the Federal Legislature as compared to the 250 officially recognized ethnic groups. It would not matter if the Central Legislature were termed a 
Tribal Assembly. Attempts should be made to contain irredentists by mieans other than suppression. Perhaps a government and a cabinet in which members of nearly all tribes are represented could provide the tranquillizing effect of office holding among the dissatisfied minorities.

The problems of national unity in African countries are to a certain extent due to the existence of strong forces of tradition side by side with modern change. In view of the fact that the changes--political, economic, and sociological-were brought about by the presence of the European powers there is a tendency to blame them. But insofar as the Africans accepted the change towards modernity they share the blame. As long as the Africans attempt to rely on tradition to cope with the modernization which they accepted, the problems are multiplied and the blame becomes diverse. It does not mean that the Africans should not preserve their cultural outiook of the African personality when it is essential to national progress but they cannot put a new wine in an old hide without a thorough mending. It also does not mean that the Africans are to be blind imitators of Furopean cultural values, but they should adopt only those values that would bring the greatest good to the greatest number. The suropean powers have given the Africans a new economic territorial area and to transform this territorial area into a political. entity should be the work of the Africans. It is true that Nigeria is a plural society, a multi-state of ancient kingdoms and 
different nationalities all lumped into one territorial sphere as the result of British influence. Most European nationstates--Britain, France, Italy and Germany--were artificially created and they have a semblance of national unity, though in their case the forces of change did not occur all at the same time. The European powers transferred their acquired experience to the Africans and what was good enough for Europe was thought good enough for the Africans. Thus if we blame the European powers too much we are failing to recognize their sense of mission which allowed them to ignore changes in terms of time and place. The Africans must accept part of the blame so that they can work out better solutions to their problems. 


\section{BIBLIGGRAPHY}

Abraham, W.E. The Mind of Africa. Chicago, 1962

Ainslie, Marion D. Nigeria A First Geography. London, 1934

Aluko, S.A. "How Many Nigerians," The Journal of Modern African Studies, 3:3 (October 1965) 371-92.

Awo. The Autobiography of Chief Obafemi Awolowo. Cambridge, 1960.

Awolowo, Obafemi. Path to Nigerian Freedom. London, 1947.

Azikiwe, Nnarndi. Political Blueprint of Nigeria. Lagos, 1943.

Batten, T.R. African in Modern History After 1800. Book III. London, 1.948 .

Bretton, Henry L. Power and Stability in Nigeria. New York, 1962.

Cameron, James. The African Revolution. New York, 1961.

Carter, Gwendolen M. National Unity and Regionalism in Eight African States. New York, 1966.

Church, Harrison R.J., John I. Clarke. Africa and the Islands. New York, 1964.

Coleman, James S. Nigeria Background to Nationalism. Berkeley, 1960.

Crowder, Michael. The Story of Nigeria. London, 1962.

Davidson, Basil. Africa: History of a Continent. New York, 1966.

Ekwensi, Cyprian. "Three Weeks Among the Fulani," Nigeria 1960. A Special Independence Issue of Nigeria Magazine TOctober 1960) 179-87.

Elias, T. Olawale, Q.C. Government and Politics in Africa. New York, 1961

New York, 1963.

Government and Politics in Nigeria. 
Flint, John E. Sir George Goldie and the Making of Nigeria. London, $19 \overline{60}$.

Hatch, John. Africa Today-And Tomocrow. New York, 1963.

Jarrett, H.R. A Geography of West Africa. London, 1956.

Judd, Peter. African Independence. New York, 1963.

Karefa-Smart, Johr, Africa: Progress Through Cooperation. New York, 1966 .

Kautsky, John H. Political Change in Underdeveloped Countries. New York, 1967.

Kopytoff, Jean Herskovits. A Preface to Modern Nigeria. Madison, 1967.

Legum, Colin.. "Great Benin the Elusive City," Nigeria 1960. A Special Independence Issue of Nigeria Magazine Toctober, 1960) 156-66.

Lugard, Arthur. The Dual Mandate in Eritish Tropical Africa. London, 1922 .

Mackintosh, John P. Nigerian Government and Politics. Evanston, 1966.

Mboya, Tom. Freedom and After. Boston, 1963.

McEwan, P.J.M. Twentieth Century Africa. London, 1968.

Mitchison, Lois. Nigeria: Newest Nation. New York, 1960.

Niven, Sir Rex. Nigeria. New York, 1967.

Nkrumah, Kwame. Africa Must Unite. New York, 1963.

Olusanya, G.O. "The Zikist Movement, 1946-1950," The Journal of Modern African Studies, $4: 3$ (November, 1966) 323-33.

Perham, Margery. Native Administration in Nigeria. London, 1937.

Potts, Margaret I. A School History of Nigeria. Hull, 1937.

Quigg, Philip W. Africa: A Foreign Affairs Reader. New York, 1964.

Quing-Young, C.T. and T. Herdman. Geography of Nigeria. London, 1946. 
Rothchild, Donald. "The Limits of Federalism in Africa," The Journal of Modern African Studies, $4: 3$ (November, 1966) 275-93.

Shepherd, George W. Jr. "National Integration and the Southern Sudan," The Journal of Modern African Studies, 4:2 (August, 1966) 200.

Sklar, Richard L. "Nigerian Political System: Contradictions," The Journal of Modern African Studies, $3: 2$ (August, 1965) 20]-13.

Thompson, Virginia and Richard Adloff, French West Africa. Stanford, 1957.

Wallerstein, Immanuei. Africa: The Politics of Independence. New York, 1961.

Zartman, I. William. "The Politics of Boundaries," The Journal of Modern African Studies, 3:2 (August, 1965) 155-73.

Zolberg, A.R. One-Party Government in the Ivory Coast, Princeton, 1964 .

African Education. Oxford: Nuffield Foundation. 1953. 47-8. Annual Report. Colony of Southern Nigeria 1906. Lagos: Government Printers.

Annual Reports. Northern Nigeria 1900-1911. Lagos: Government Printers.

Population Census of the Western Region of Nigeria 1952. Lagos: Government Statistician. 1953-4.

Population Census of the Northern Region of Nigeria 1952. Lagos: Government Statistician. 1952-3.

Population Census of the Eastern Region of Nigeria 1953. Lagos: Government Statistician. 1954.

The Economic Development of Nigeria. A Report for the International Eank for Reconstruction and Development. Baltimore, 1955. 